\title{
The Alaska Mineral Resource Assessment Program-Background Information to Accompany Geologic and Mineral-Resource Maps of the Valdez Quadrangle, South-Central Alaska
}




\section{AVAILABILITY OF BOOKS AND MAPS OF THE U.S. GEOLOGICAL SURVEY}

Instructions on ordering publications of the U.S. Geological Survey, along with the last offerings, are given in the current-year issues of the monthly catalog "New Publications of the U.S. Geological Survey." Prices of available U.S. Geological Survey publications released prior to the current year are listed in the most recent annual "Price and Availability List." Publications that are listed in various U.S. Geological Survey catalogs (see back inside cover) but not listed in the most recent annual "Price and Availability List" are no longer available.

Prices of reports released to the open files are given in the listing "U.S. Geological Survey Open-File Reports," updated monthly, which is for sale in microfiche from the U.S. Geological Survey Books and Open-File Reports Sales, Box 25425, Denver, CO 80225.

Order U.S. Geological Survey publications by mail or over the counter from the offices given below.

\section{BY MAIL}

\section{Books}

Professional Papers, Bulletins, Water-Supply Papers, Techniques of Water-Resources Investigations, Circulars, publications of general interest (such as leaflets, pamphlets, booklets), single copies of periodicals (Earthquakes \& Volcanoes, Preliminary Determination of Epicenters), and some miscellaneous reports, including some of the foregoing series that have gone out of print at the Superintendent of Documents, are obtainable by mail from

\section{U.S. Geological Survey, Books and Open-File Report Sales} Box 25425

Denver, CO 80225

Subscriptions to periodicals (Earthquakes \& Volcanoes and Preliminary Determination of Epicenters) can be obtained ONLY from

\section{Superintendent of Documents \\ U.S. Government Printing Office \\ Washington, DC 20402}

(Check or money order must be payable to Superintendent of Documents.)

\section{Maps}

For maps, address mail order to

$$
\begin{gathered}
\text { U.S. Geological Survey, Map Sales } \\
\text { Box 25286 } \\
\text { Denver, CO 80225 }
\end{gathered}
$$

Residents of Alaska may order maps from

$$
\begin{aligned}
& \text { U.S. Geological Survey, Map Sales } \\
& 101 \text { Twelfth Ave., Box } 12 \\
& \text { Fairbanks, AK } 99701
\end{aligned}
$$

\section{OVER THE COUNTER}

\section{Books}

Books of the U.S. Geological Survey are available over the counter at the following U.S. Geological Survey offices, all of which are authorized agents of the Superintendent of Documents.

- ANCHORAGE, Alaska-4230 University Dr., Rm. 101

- ANCHORAGE, Alaska-605 West 4th Ave., Rm G-84

- DENVER, Colorado-Federal Bldg., Rm. 169, 1961 Stout St.

- LAKEWOOD, Colorado-Federal Center, Bldg. 810

- MENLO PARK, California-Bldg. 3, Rm. 3128, 345 Middlefield Rd.

- RESTON, Virginia-National Center, Rm. 1C402, 12201 Sunrise Valley Dr.

- SALT LAKE CITY, Utah-Federal Bldg., Rm. 8105, 125 South State St.

- SAN FRANCISCO, California-Customhouse, Rm. 504, 555 Battery St.

- SPOKANE, Washington-U.S. Courthouse, Rm. 678, West 920 Riverside Ave.

- WASHINGTON, D.C.-U.S. Department of the Interior Bldg., Rm. 2650, 1849 C St., NW.

\section{Maps}

Maps may be purchased over the counter at the U.S. Geological Survey offices where books are sold (all addresses in above list) and at the following Geological Survey offices:

- ROLLA, Missouri-1400 Independence Rd.

- FAIRBANKS, Alaska-New Federal Building, 101 Twelfth Ave. 
The Alaska Mineral Resource Assessment ProgramBackground Information to Accompany Geologic and Mineral-Resource Maps of the Valdez Quadrangle, South-Central Alaska

By G.R. WINKLER, R.J. GOLDFARB, W.J. PICKTHORN, and GEORGE PLAFKER 


\title{
U.S. DEPARTMENT OF THE INTERIOR \\ MANUEL LUJAN, JR., Secretary
}

\author{
U.S. GEOLOGICAL SURVEY \\ Dallas L. Peck, Director
}

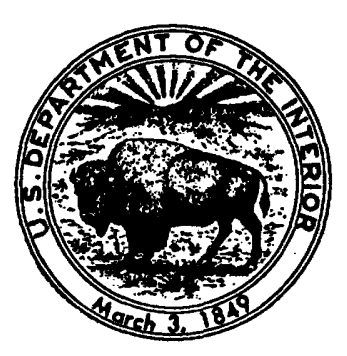

Any use of trade, product, or firm names in this publication is for descriptive purposes only and does not imply endorsement by the U.S. Government

UNITED STATES GOVERNMENT PRINTING OFFICE: 1992

Free on application to

Book and Open-File Report Sales

U.S. Geological Survey

Federal Center, Box 25425

Denver, CO 80225

Library of Congress Cataloging-in-Publication Data

The Alaska mineral resource assessment program : background information to accompany geologic and mineral-resource maps of the Valdez Quadrangle, southcentral Alaska / by G.R. Winkler ... [et al.].

p. cm. - (U.S. Geological Suney circular ; 1087)

Includes bibliographical references.

Supt. of Docs. no.: I 19.4/2: 1087

1. Geology-Alaska-Valdez Region. 2. Mines and mineral resourcesAlaska-Valdez Region. 3. Alaska Mineral Resource Assessment

Program. I. Winker, Gary R. II. Series.

QE84.V36A42 1992

92-11017

$557.98^{\prime} 3-\mathrm{dc} 20$ 


\section{CONTENTS}

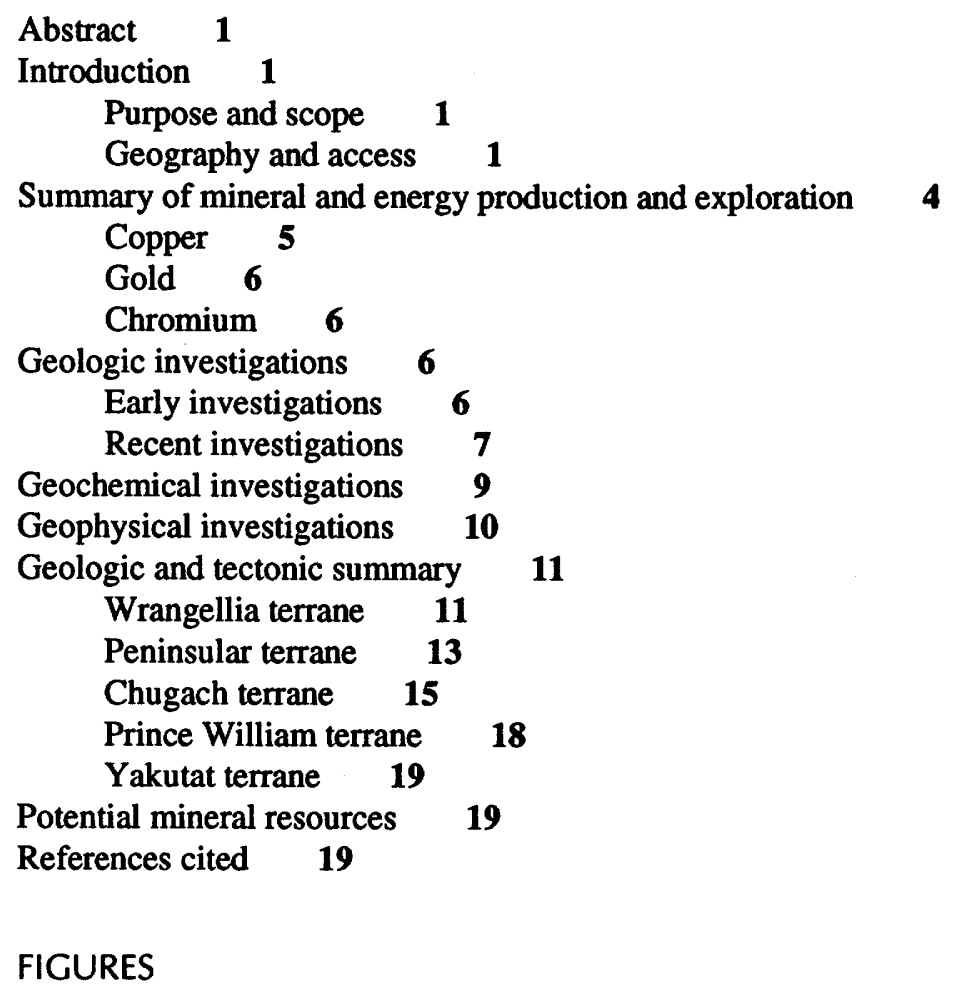

1-3. Maps showing:

1. Selected geographic features of the Valdez quadrangle 3

2. Generalized geology of the Valdez quadrangle 12

3. Geologic terranes of the southern Alaska region 14

\section{TABLE}

1. Geologic, geochemical, geophysical, and mineral-resource maps of the Valdez $1^{\circ} \times 3^{\circ}$ quadrangle, Alaska 2 



\title{
The Alaska Mineral Resource Assessment Program- Background Information to Accompany Geologic and Mineral-Resource Maps of the Valdez Quadrangle, South-Central Alaska
}

\author{
By G.R. Winkler, R.J. Goldfarb, W.J. Pickthorn, and George Plafker
}

\begin{abstract}
The Valdez $1^{\circ} \times 3^{\circ}$ quadrangle in south-central Alaska contains potentially significant resources of gold, chromium, copper, and possibly a few other commodities. This report summarizes recent results of integrated geological, geochemical, and geophysical field and laboratory studies conducted by the U.S. Geological Survey that were designed to provide an assessment of the mineral resources of the quadrangle. The results have been published principally as maps and data releases in U.S. Geological Survey Open-File Reports and Miscellaneous Field Studies maps, which are cited herein and provide background information for the assessment. This report also cites numerous additional references for published reports and maps that describe the mineral resources and the geologic and tectonic setting of the Valdez quadrangle.
\end{abstract}

\section{INTRODUCTION}

\section{Purpose and Scope}

Recent U.S. Geological Survey field and laboratory studies of the geologic setting of mineral and energy deposits in the Valdez $1^{\circ} \times 3^{\circ}$ quadrangle in south-central Alaska were conducted as part of the Alaska Mineral Resource Assessment Program (AMRAP), mineral surveys of public lands within Chugach National Forest, and the Trans-Alaska Crustal Transect (TACT) study of the deep crustal structure of southern Alaska. The overall objective of the geologic, geochemical, and geophysical investigations was to provide modern mineral-resource information as potential input for land-use planning and minerals-policy development and to

Manuscript approved for publication April 3, 1992. guide minerals exploration. The studies also aimed to enhance the geologic knowledge of an area that had received few recent earth-science investigations. These studies were completed in 1988; however, they incorporate much fundamental geologic information that was obtained in the 1950's, 1960's, and 1970's during studies of the Copper River Basin area, the Gulf of Alaska Tertiary province, the epicentral region of the 1964 Alaska earthquake, the major fault systems of southern Alaska, and the mineral resources of the contiguous McCarthy $1^{\circ} \times 3^{\circ}$ quadrangle to the east. A list of maps and reports that provide the primary mineral-resource data for the Valdez quadrangle is given in table 1. Other sources of information on the geology and mineral deposits of the quadrangle are cited in the text and listed in the accompanying references.

\section{Geography and Access}

The Valdez quadrangle includes about $18,000 \mathrm{~km}^{2}$ of south-central Alaska (fig. 1). The quadrangle is bounded by the $61^{\circ}$ and $62^{\circ}$ parallels and by the $144^{\circ}$ and $147^{\circ}$ meridians. The quadrangle includes, from north to south, the southwest end of the scenic Wrangell Mountains dominated by the broad shield volcano of Mount Wrangell, part of the lowlands of the Copper River Basin drained by the Copper River and numerous tributaries, and the rugged, glacier-clad crest of the Chugach Mountains indented on the southwest by the fiord of Port Valdez. Mount Wrangell is still mildly active, and periodically small ash eruptions darken snowfields near the summit crater.

Near the village of Chitina at the southern margin of the Copper River Basin, the Chitina River joins the Copper River from the east to form Alaska's third most voluminous drainage (fig. 1). Below the confluence, the Copper River flows south across the Chugach Mountains through a deep 
Table 1. Geologic, geochemical, geophysical, and mineral-resource maps of the Valdez $1^{\circ} \times 3^{\circ}$ quadrangle, Alaska

\begin{tabular}{|c|c|}
\hline Reference & Subject \\
\hline Cobb and Matson (1972) & $\begin{array}{l}\text {............ Location, identification, and reported commodities of known lode and } \\
\text { placer deposits. }\end{array}$ \\
\hline Cobb (1979) & ............ Compilation of references on mineral-resource occurrences. \\
\hline U.S. Geological Survey (1979) & ........... Aeromagnetic survey. \\
\hline Winkler, Miller, MacKevett, and Holloway (1981) & ............ Characteristics and geologic controls of mineral-resource occurrences. \\
\hline Winkler, Silberman, and others (1981) & ............ Bedrock geology and K-Ar geochronology. \\
\hline Williams and Johnson (1981) & ............ Surficial geology. \\
\hline Le Compte (1981) & ............ Interpretation of satellite imagery. \\
\hline Miller and others (1982) & ............ Geochemical survey; analytical results and sample locality maps. \\
\hline Case, Burns, and Winkler (1986) & ............ Aeromagnetic map and interpretation. \\
\hline Goldfarb and others (in press) & $\begin{array}{l}\text { Geochemical interpretation; maps and tabulations of areas with } \\
\text { geochemical anomalies for metals. }\end{array}$ \\
\hline Pickthorn and others (in press) & $\begin{array}{l}\text { Mineral-resource assessment; delineation and characterization of } \\
\text { areas having potential for undiscovered resources of precious, base, } \\
\text { and ferrous metals. }\end{array}$ \\
\hline
\end{tabular}

canyon to be joined at the southern boundary of the quadrangle by the Tasnuna and Bremner Rivers. Other major tributaries, such as the Klutina and Tonsina Rivers, originate in glaciers near the crest of the Chugach Mountains and flow northward into the Copper River Basin. Where these rivers emerge from the mountains, they flow into large lakes impounded by terminal moraines that mark the maximum advance of former valley glaciers. The glaciers have receded tens of kilometers southward to leave remnants near the crest of the Chugach Mountains. All of these rivers have large seasonal flows and carry enormous loads of sediment, which are being deposited as broad alluvial plains encroaching upon the lakes or transported to the turbid Copper River to be carried to its coastal delta in the Cordova quadrangle to the south. South of the crest of the Chugach Mountains, the Lowe River and drainages from the Valdez Glacier also carry a large load of sediment, which is deposited as a steepfronted delta in deep water where the rivers meet tidewater in Port Valdez.

Topographic relief in the quadrangle exceeds $4,250 \mathrm{~m}$, from sea level in Port Valdez to the crater rim of Mount Wrangell. Most ridges in the Chugach and Wrangell Mountains are rugged and steep sided, having been quarried by and submerged beneath glaciers until recently. The two mountain ranges are separated by broad open lowlands along the Copper and Chitina Rivers.

The earliest published descriptions of the geography and geology of parts of the Valdez quadrangle resulted from expeditions in 1885 and 1891 (Allen, 1887; Hayes, 1892) that generally followed the Copper and Chitina Rivers. The discovery of rich placer gold deposits on the Klondike River in the Yukon Territory of Canada prompted more thorough exploration as well as a stampede of fortune hunters. At least 4,000 people landed at Valdez during the winter of 1897-1898 with the intention of being among the first to reach the gold fields in the spring of 1898 (Schrader, 1900); most lacked any experience in pioneering or mining. A few remained to prospect the local drainages for placer gold or the Prince William Sound region for lodes of copper; however, about 3,000 stampeders endured severe hardships to pioneer routes from the coast to the interior that soon became trails or roads. Today's Richardson Highway from Valdez to Copper Center follows what was the most common route. In 1899 and 1900, bonanza copper lodes were discovered near Kennicott ${ }^{1}$ Glacier in the southern Wrangell Mountains. Between 1905 and 1911, the Copper River \& Northwestern Railway was constructed more than $200 \mathrm{~km}$ from Cordova up the Copper River Canyon to Chitina from which it extended approximately another $100 \mathrm{~km}$ eastward to the mines in the McCarthy quadrangle. Between 1911 and 1938, more than 1.2 billion pounds of copper and 9 million troy ounces of silver from the Kennecott mines (Douglass, in MacKevett and others, 1977) were carried by the railroad through Chitina to shipping docks on tidewater at Cordova. Production ceased in 1938, and most of the rails were salvaged for scrap metal during World War II. The roadbed later was regraded between Chitina and McCarthy, and in the late 1960's a new bridge was constructed across the Copper River; in the summer months, the road now is maintained for passenger vehicles. An unmaintained spur road extends northward from the former transfer point of Strelna following a preexisting trail to mineral prospects on the Kotsina River; it becomes virtually impassable, however, within a short distance from Strelna. From Chitina, an early trail called the Edgerton Cutoff now has been widened and paved

\footnotetext{
${ }^{1}$ The company formed to develop the copper properties took its name from the nearby glacier, which had been named for a pioneer surveyor in the region, but somehow (probably inadvertently), an " $e$ " was substituted for an "i" in the spelling of Kennecott Copper Corporation.
} 


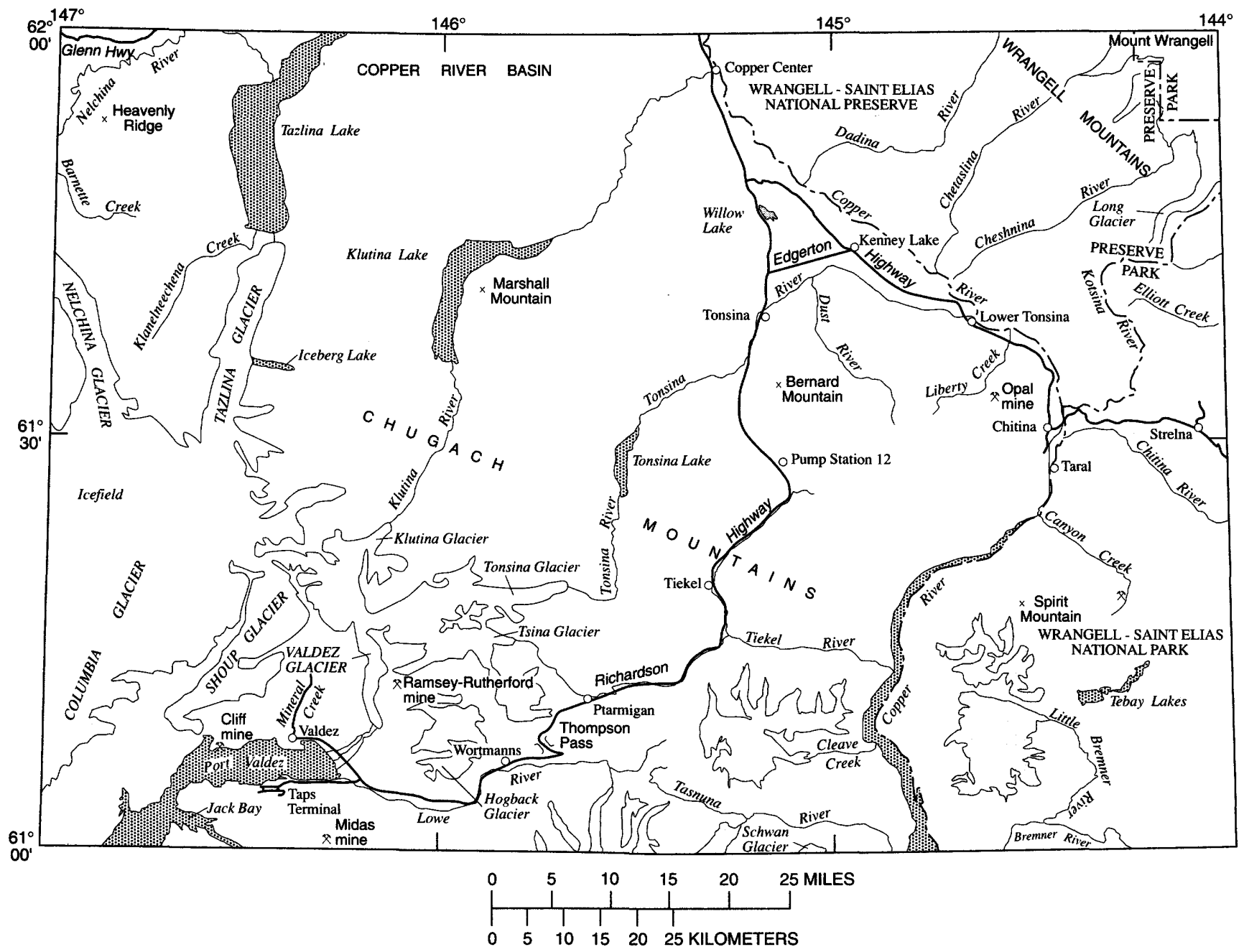

Figure 1. Selected geographic features of the Valdez quadrangle. Heavy stippling indicates tidewater or lakes; light shading indicates glaciers or permanent ice fields.

and extends northwestward to reach the Richardson Highway near the historic Tonsina roadhouse. A short segment of the Glenn Highway runs through the northwest corner of the Valdez quadrangle. It follows one of the earliest trails from upper Cook Inlet to the interior of Alaska and is the most direct route for highway travel between the metropolis of Anchorage and Glennallen. The southern end of the TransAlaska Pipeline System (TAPS) follows the Richardson Highway closely across most of the Valdez quadrangle. During its construction in the mid-1970's, large camps were maintained near the old road houses of Wortmanns, Ptarmigan, Tiekel, and Tonsina; the only remaining TAPS facilities, however, are the southernmost pump station (no. 12) at which the oil is heated and speeded for its ascent over Thompson Pass on the final leg of its 1,250-km journey from Prudhoe Bay to the pipeline terminus and marine shipping facility on the south side of Port Valdez.

Prior to the 1964 Alaska earthquake, the town of Valdez was located on the composite delta formed by the Lowe and
Valdez Glacier Rivers. Following catastrophic submarine sliding of the seaward part of the delta during the earthquake, much of the settlement that remained standing was inundated by slide-generated waves. The town subsequently was rebuilt in its present location behind bedrock headlands along the north shore of Port Valdez. When it became a shipping and staging area during construction of the southern end of the TAPS, Valdez burgeoned to become a city; it now is Alaska's 14th largest city and has a population (1990) of 4,635 . Valdez has year-round harbor facilities. It is the base for a large fleet of fishing and pleasure vessels, a port of call for ferries on the Alaska Marine Highway system, and headquarters for U.S. Coast Guard facilities that monitor shipping in Prince William Sound and oil tanker traffic to and from the TAPS marine facility near the head of Port Valdez. Valdez also is served by an all-weather airport with daily service.

Copper Center is the only other town in the quadrangle; its 1990 population was 449. Most residents are Alaska 
Natives of the Copper River Athabascan tribe; the headquarters for the AHTNA, Inc., Regional Native Corporation is located a few kilometers north of Copper Center. Population elsewhere in the quadrangle is sparse and fluctuates seasonally. Permanent settlements are located at Chitina, Lower Tonsina, and Kenney Lake on the Edgerton Highway, numerous homesteads and hay farms are in the surrounding area, and seasonal cabins or lodges are on the shores of several outlying lakes. The transient population increases markedly during the summer months. Copper Center and Chitina have long graded runways and frequent seasonal air service; several shorter landing strips provide air access to scattered places in the quadrangle.

All of the Valdez quadrangle east of the Copper River is included within the Wrangell-Saint Elias National Park and Preserve, which was created in December 1980 by enactment of the Alaska National Interest Lands Conservation Act (ANILCA). The Park headquarters is a few kilometers from Copper Center just north of the quadrangle boundary.

Acknowledgments.- Many colleagues participated in the earth-science investigations of the Valdez quadrangle that are summarized in this circular. We gratefully acknowledge their important contributions, many of which are cited in the accompanying list of references. In particular, the detailed geologic mapping and stratigraphic studies of E.M. MacKevett, Jr., and his coworkers in the McCarthy quadrangle and the regional studies of George Plafker and his coworkers of the Border Ranges fault system and other major faults in southern Alaska provided the vital framework on which subsequent AMRAP and TACT investigations were built. Colleagues who made important contributions to the AMRAP geologic, geochemical, and geophysical studies in the quadrangle include D.F. Barnes, D.L. Campbell, J.E. Case, C.L. Connor, Arthur Grantz, C.D. Holloway, K.M. Johnson, J.R. Le Compte, R.J. Miller, R.L. Morin, W.J. Nokleberg, R.M. O’Leary, M.L. Silberman, S.C. Smith, S.J. Sutley, R.B. Tripp, R.G. Tysdal, and J.R. Williams of the U.S. Geological Survey; L.E. Burns and G.H. Pessel of the State of Alaska Division of Geological and Geophysical Surveys; T.L. Hudson, ARCO Alaska, Inc.; and R.J. Newberry and W.K. Wallace, University of Alaska-Fairbanks.

\section{SUMMARY OF MINERAL AND ENERGY PRODUCTION AND EXPLORATION}

Lode mines in the Valdez quadrangle produced gold, copper, and silver, and probably lead and zinc, in the first three decades of the 20th century, principally in the Port Valdez and Tonsina districts between 1910 and 1929. The characteristics and probable geologic controls of known mines, prospects, and occurrences in the quadrangles are summarized by Winkler, Miller, MacKevett, and Holloway (1981). During the gold rush to the Klondike and exploration and development of copper mines near McCarthy in the
Wrangell Mountains and near Latouche and Ellamar in Prince William Sound, prospecting for gold and copper was widespread; many claims were located and some were developed throughout the quadrangle area. Dilapidated structures in the Chugach Mountains on Columbia and Shoup Glaciers, above Mineral Creek, east of Valdez Glacier, Solomon Gulch, between the Tiekel and Tonsina Rivers, between Taral and Canyon Creeks, between Marshall Mountain and Klutina Lake, and on Barnette Creek, in the Wrangell Mountains on the upper reaches of Elliott Creek and the Kotsina River, and along the route of the Copper River \& Northwestern Railroad are vestiges of this era. No properties outside the Port Valdez and Tonsina districts are known to have produced metals, with the possible exception of minor gold production from small lodes west of Chitina in the late 1970 's and early 1980's. Placer gold production from the Valdez quadrangle apparently has been very minor, although most drainages near known auriferous lodes have showings.

Bulldozer trenches that explore iron-stained zones in calc-schist and greenschist on the Chetaslina River in the Wrangell Mountains are of uncertain vintage but may date from the late 1960 's or early 1970 's. The trenches expose small veins containing pyrite, chalcopyrite, and barite; samples contain trace to minor amounts of detectable gold. In the mid-1970's, active development began on the Opal claims on the upland surface between Liberty and Fivemile Creeks west of Chitina (Winkler, Miller, MacKevett, and Holloway, 1981). The claims encompass numerous widely spaced quartz veins that cut semischistose rocks of the McHugh Complex and Eocene tonalite. The veins contain arsenopyrite, pyrite, galena, and sphalerite and have anomalous values of gold and silver. The claims currently are active, and there probably has been minor production of precious metals.

Exploratory drilling for petroleum was conducted during the 1960's in the southwestern part of Copper River Basin just north of the quadrangle boundary (Alaska Geological Society, 1970). The test wells bottomed between 850 and $2,700 \mathrm{~m}$ in Jurassic or Cretaceous marine rocks, testing possible structural and stratigraphic traps in the Mesozoic section. The wells penetrated as much as $600 \mathrm{~m}$ of Tertiary nonmarine coal-bearing shale, sandstone, and conglomerate correlative with the Chickaloon Formation, 1,500-1,900 m of Lower and Upper Cretaceous rocks correlative with the Nelchina Limestone and Matanuska Formation, and as much as 1,200 $\mathrm{m}$ of Middle and Upper Jurassic rocks correlative with the Chinitna and Naknek Formations and the Tuxedni Group in the nearby Nelchina area and the Kotsina Conglomerate in the Wrangell Mountains (Arthur Grantz, U.S. Geological Survey, oral commun., 1991). At least two wells reached the Talkeetna Formation. Apparently no encouraging shows were encountered in the Mesozoic rocks. The wells also tested without success the possibility that petroliferous Tertiary nonmarine sequences that are productive in upper Cook Inlet might be present in the area. 
Heat flux at the summit crater of Mount Wrangell increased notably during the 1970's (Benson and Motyka, 1979), causing melting of the summit ice cap and seasonal exposure of bare ground on the north slope of the crater. Intermittent ash falls darkened the summit area. Although the volume of the magma chamber under Mount Wrangell is estimated to be approximately $50 \mathrm{~km}^{3}$ (Smith and Shaw, 1975), its potential use as a large-scale source of geothermal power is limited by its lofty elevation and its remoteness from potential power demand. Areas of abnormally high heat flux are not known at lower elevations on the west flank of the volcano, where development would be less hazardous and costs less prohibitive.

Recent exploration activity in the quadrangle has been quite limited and has focused mainly on the search for massive sulfide deposits, precious metal veins or lodes, and chromium, nickel, or platinum-group elements hosted in layered mafic-ultramafic igneous complexes. No major discoveries have been announced; however, several discoveries, including some resulting from our own investigations, may be significant, and they warrant additional detailed evaluation.

\section{Copper}

Although the use of native copper implements by interior and coastal Alaska Native peoples had been known for more than a hundred years, their provenance was not revealed until the late summer of 1899 when prospectors were led to occurrences in the McCarthy area by an informant of Chief Nikolai, head of the Taral band of the Copper River Indians. Claims also were staked in upper Elliott Creek in 1899. Prospecting soon focused on the Nikolai Greenstone-Chitistone Limestone contact near which most occurrences were located. The subsequent discovery of the Bonanza lode in the summer of 1900 in the McCarthy quadrangle intensified prospecting throughout south-central Alaska for Kennecotttype deposits. Most occurrences that crop out near the contact were discovered between 1900 and 1902 (Mendenhall and Schrader, 1903). For example, prospects in the mountains east of Taral were located in 1901 (Moffit, 1912, 1914). The practical access that was provided by completion of the railroad in April 1911 prompted another two-year spurt in prospecting during which several additional properties were discovered. Within the northern part of the Valdez quadrangle, however, most copper occurrences are in veins of limited extent or associated small pods, disseminations, or surface coatings (Winkler, Miller, MacKevett, and Holloway, 1981). Most are in or near fractures or faults and exhibit hydrothermally altered wallrock. MacKevett (1976) inferred that similar deposits in the McCarthy quadrangle were produced by hydrothermal process related to Late Jurassic or Tertiary plutonism, an inference that probably is equally warranted for deposits in the Valdez quadrangle. Few, if any, of the deposits in the Valdez quadrangle display features of sabkha remobilization that typify the largest and richest lodes of the Kennecott type (Armstrong and MacKevett, 1976, 1982). None of the numerous deposits on Elliott Creek or the Kotsina or Cheshnina Rivers in the Wrangell Mountains or the lodes in the Chugach Mountains on the uplands between Taral Creek and Divide Creek were able to compete with the phenomenally rich Kennecott lodes, which during 26 years of shipments averaged about 13 percent copper (Douglass, in MacKevett and others, 1977).

Active prospecting for submarine volcanogenic deposits of copper began in the Prince William Sound region in 1897 with the staking of claims in the Ellamar area just south of the Valdez quadrangle boundary (Grant and Higgins, 1910). The Midas mine in Solomon Gulch near Valdez was discovered in 1901, and the first shipment of ore occurred in 1912 (Johnson, 1915). Between 1912 and 1919, the two lodes at the mine produced more than 500 tons of copper (Moffit and Fellows, 1951); ore shipments also contained between 0.25 and $0.42 \mathrm{oz} /$ ton silver and 0.05 and $0.062 \mathrm{oz} /$ ton gold (Rose, 1965). Ore remains underground. Jansons and others (1984) estimated additional reserves of 62,000 tons of 1.6 percent copper. Prospects south of the divide in Jack Bay apparently are much smaller and lower grade (Johnson, 1919). Prospects several kilometers to the east near Sulphide Gulch (Johnson, 1916) probably have greater tonnage but are significantly lower grade (Rose, 1965). Additional occurrences at Wortmanns and Tsina Glaciers (Winkler, Miller, MacKevett, and Holloway, 1981) also probably are large, low-grade deposits. Many of the larger deposits, such as those of the Midas mine, are hosted by sedimentary rocks, indicating that they are of the Besshi-type of volcanogenic massive sulfide deposit (Nelson and Koski, 1987; Crowe and others, in press).

During the regional prospecting induced by the Kennecott finds, massive copper-nickel sulfide lenses were discovered about 1907 near Spirit Mountain in peridotite dikes intruding schist, gneiss, and marble. The prospect was abandoned in 1917 (Overbeck, 1918). Because of the strategic importance of nickel during World War II, the prospect was reevaluated in 1942 and found to contain minor amounts of cobalt, as well as the nickel and copper (Kingston and Miller, 1945). Estimated reserves included 6,500 short tons of material grading from 0.22 to 7.61 percent nickel and 0.12 to 1.56 percent copper; however, the relative inaccessibility of the prospect and its small tonnage and low grade were deemed to make it subeconomic, even under the favorable price conditions prevailing at that time (Kingston and Miller, 1945). Additional investigations in the late 1960's (Herreid, 1970) and late 1980's (Foley and others, 1989) demonstrated that the massive sulfide lenses also contained minor values of silver and platinum-group elements (chiefly palladium), but there has been no subsequent development activity. 


\section{Gold}

Pay gravels had been known on many of the streams near Valdez as early as 1894 , when minor sluicing was underway on Mineral Creek (Schrader, 1900), and nearby quartz veins were staked as early as 1897 . Valdez principally was regarded, however, as a starting point for the interior until the Cliff mine was located in 1906 and began to produce gold in 1910 (Johnson, 1915). Prompted by its success, in 1909 and 1910 prospectors located numerous additional occurrences in a large area extending from Valdez Glacier west to Columbia Glacier (Brooks, 1912). Additional deposits that soon became productive, including the CameronJohnson on Shoup Glacier and the Rose Johnson and the Ramsey-Rutherford east of Valdez Glacier, were discovered in 1911; by 1914, nine mills of various types were in operation in the productive area north of Port Valdez, which came to be included in the Port Valdez district. During its lifetime, more than 61,000 ounces of gold were produced from lode deposits in the district (Jansons and others, 1984).

Gold-bearing quartz veins south of Port Valdez are included in the Jack Bay district. The area was thoroughly prospected between 1910 and 1915, but workings are small and no gold is known to have been produced; however, significant unrecorded gold production from the copper ores of the Midas mine is likely.

Many of the streams draining northward into the Copper River Basin or eastward into the Copper River had placer activity around the turn of the century before any workable quartz veins were discovered (Rohn, 1900; Schrader, 1900; Brooks, 1914); however, only the gravels on Quartz and Fall Creeks are known to have produced small amounts of gold (Moffit, 1918, 1935). Jansons and others (1984) evaluated the placer gold potential of many of the tributaries of the Lowe and Tasnuna Rivers along the southern edge of the Valdez quadrangle. They found significant showings below Marshall Glacier and sites having moderate placer potential along Bench Creek (a tributary of the Lowe River at the mouth of Heiden Canyon) and Cleave Creek (a tributary of the Copper River upstream from the mouth of the Tasnuna River) and in the alluvial flats of the Tasnuna River between its junction with the Copper River and the Schwan Glacier.

The development of the Cliff mine near Valdez stimulated extensive prospecting for lode sources of gold along the route of the Richardson Highway beginning in 1911 . Most of the gold-bearing quartz veins near Tiekel in the Tonsina district were discovered within a few years thereafter (Moffit, 1918). Only properties on the east side of Hurtle Creek and near the head of Boulder Creek are known to have produced gold, although there also was extensive development of claims near Stuart Creek in the 1920's (Moffit, 1935).

Gold placers were discovered on the Little Bremner River in 1901 and probably produced small quantities of gold in the first two decades of the 20th century (Moffit,
1912, 1914). No lode occurrences are known to be present in the drainage.

In the Wrangell Mountains, gold-bearing quartz veins cutting mafic volcanic rocks and gabbro along Benito Creek were discovered in 1913 (Moffit and Mertie, 1923); they have been prospected intermittently to the present time, but there has been no development.

\section{Chromium}

Chromite was discovered at Bernard Mountain near Tonsina in 1954, and by 1956 claims had been extended more than $5 \mathrm{~km}$ to the northeast to include exposures of layered ultramafic rocks at so-called "Sheep Hill" west of Dust Creek (Foley and Barker, 1985). U.S. Government incentive prices under the Minerals Stockpile Program were halted in 1956 before the deposits could be developed, and the claims were allowed to lapse soon thereafter. From time to time in the ensuing years, small-scale investigations have been renewed in the Bernard Mountain area, but no major activity has occurred. The U.S. Bureau of Mines has identified resources in three deposits at Bernard Mountain that exceed 343,000 tons $\mathrm{Cr}_{2} \mathrm{O}_{3}$; one deposit at Sheep Hill is estimated to contain 26,000 tons $\mathrm{Cr}_{2} \mathrm{O}_{3}$ (Foley and Barker, 1985). Chromian spinels in dunite and peridotite at these locations are anomalous in platinum-group elements and in clinopyroxenite also contain anomalous gold (Foley and Barker, 1987). Nearby, magmatic-sulfide prospects in layered gabbroic rocks near the benchmark "Scarp" contain as much as 5 percent pyrite and lesser marcasite and chalcopyrite (Newberry, 1986). Near the head of Barnette Creek in the western part of the Valdez quadrangle, small test pits of uncertain vintage also have been excavated on stringers of chromite in sheared ultramafic rocks (Winkler, Miller, MacKevett, and Holloway, 1981), and disseminated and irregular masses of chalcopyrite, pyrrhotite, and lesser pentlandite are present in layered gabbronorite at several locations between the Nelchina and Tazlina Glaciers (Newberry, 1986; G.R. Winkler, unpublished data); however, these occurrences are remote and very limited in extent. Other bodies of serpentinized ultramafic rocks emplaced near or along the Border Ranges and Second Lake fault zones along the north flank of the Chugach Mountains are essentially unexplored.

\section{GEOLOGIC INVESTIGATIONS}

\section{Early Investigations}

The earliest published geologic observations from the Valdez quadrangle are incidental products of two pioneering U.S. Army expeditions into the largely unexplored interior of Alaska. The first expedition, under the direction of Lieutenant H.T. Allen, in 1885 explored the main valleys of the 
Copper and Chitina Rivers on the way to the interior (Allen, 1887). The second, which was led by Lieutenant Frederick Schwatka and included geologist C.W. Hayes, in 1891 descended the Chitina and Copper Rivers on the way from the interior (Hayes, 1892). In 1898, F.C. Schrader of the Geological Survey was assigned to the Copper River military explorations under Captain W.R. Abercrombie; Schrader (1900) made extensive observations on a trip that began at Valdez, reached the Copper River Basin by way of Valdez and Klutina Glaciers, and returned to Valdez via the Copper, Tasnuna, and Lowe Rivers. The Harriman Alaska Expedition visited Prince William Sound in 1899 and provided detailed descriptions of Columbia Glacier for the first time (Gilbert, 1904). Oscar Rohn's geologic circuit of the Wrangell Mountains from Valdez in 1899 (Rohn, 1900) led to the beginning of systematic U.S. Geological Survey investigations in the area in 1900. Schrader and Spencer (1901) conducted the first detailed geologic studies of parts of Prince William Sound, the Copper River Basin, and the southwestem Wrangell Mountains. Mendenhall and Schrader (1903) and Mendenhall (1905) provided the first surveys of the western part of the copper belt in the Wrangell Mountains, and detailed studies of the Kotsina-Kuskulana area were continued by F.H. Moffit and his coworkers (Moffit and Maddren, 1909; Moffit and Capps, 1911; Moffit, 1918; Moffit and Mertie, 1923). Grant (1906, 1909), Moffit (1908), Grant and Higgins (1909), Brooks (1912, 1914), and Capps and Johnson $(1913,1915)$ provided early reports on copper and gold mining and prospecting in Prince William Sound during the period of greatest activity. Grant and Higgins (1910) provided a regional summary of the geologic knowledge of Prince William Sound that was gained during the first decade of investigations, and Johnson (1915, 1916, 1919) continued detailed studies of copper and gold occurrences in the northeastern part of the sound. During this same period, F.H. Moffit also investigated the geologic setting of copper and gold resources in the Chugach Mountains, first east of the Copper River (Moffit, 1912, 1914) and then west of the river in the Tonsina district (Moffit, 1918, 1935). In 1917, Overbeck (1918) completed a brief examination of the copper-nickel prospects near Spirit Mountain east of the Copper River.

Following these pioneering geological studies, the focus of most investigations shifted to other regions of Alaska until the 1940 's and 1950's, when some activity resumed in southern Alaska. The resumption was prompted largely by cutoffs or limitations in supplies of strategic commodities prior to and during World War II and the Korean War. Investigations of the copper-nickel prospects near Spirit Mountain were renewed during 1942 (Kingston and Miller, 1945), and the copper deposits of the Prince William Sound region were reevaluated in 1943 (Moffit and Fellows, 1951). F.H. Moffit's culminating report on Prince William Sound (Moffit, 1954) provides a wealth of basic information on the geologic setting of the region. In the early 1950's, the U.S. Govern- ment was purchasing chromite concentrates at incentive prices under the Mineral Stockpile Program. The U.S. Bureau of Mines conducted several evaluations of chromite occurrences in southern Alaska in the late 1940's and 1950's, including extensive assays and mineral dressing tests of samples in 1957 from the chromite deposits near Tonsina (Pittman, Wells in Foley and Barker, 1985).

\section{Recent Investigations}

As part of a program of petroleum investigations in southern Alaska (Miller and others, 1959), the U.S. Geological Survey began stratigraphic and structural studies in the Nelchina area in the 1950's. The petroleum potential of Mesozoic rocks on the west, shore of Cook Inlet was well known, but the correlation of these rocks with Mesozoic sequences that are exposed widely in the eastern Talkeetna Mountains and western Copper River Basin was virtually unstudied. Through detailed geologic mapping and biostratigraphic studies, Arthur Grantz and numerous colleagues were able to correlate Jurassic sequences in the two regions (summarized in Grantz, 1965, and Imlay and Detterman, 1973). The Cretaceous rocks in the eastern Talkeetna Mountains, however, differ from coeval rocks on the west shore of Cook Inlet and are assigned to the Matanuska Formation (summarized by Grantz, 1964). During subsequent reconnaissance work in the southwestern Wrangell Mountains, Grantz and others (1966) described Upper Jurassic(?) and Lower Cretaceous rocks near Chitina that are temporal equivalents of the Nelchina rocks.

Also in the 1950's, the U.S. Geological Survey began studies of the thick and complexly intertonguing upper Tertiary and Quaternary deposits of the Copper River Basin, work that continued with interruptions until the early 1980's. The focus of the early work was to distinguish and define local and regional glacial deposits that capped the mountains and filled much of the basin in late Wisconsin time (Nichols, 1965; Ferrians and Nichols, 1965) and also filled Port Valdez (Williams and Coulter, 1980). At the outset, it was apparent that the Copper River Basin contains an array of unconsolidated deposits including lacustrine deposits of glacial Lake Atna (Ferrians and Schmoll, 1957; Nichols, 1965) and lava flows and volcaniclastic debris flows from the Wrangell Mountains that are interbedded with glacial deposits (Nichols and Yehle, 1969; Yehle and Nichols, 1980). The lake persisted during retreat of the glaciers into the mountains, as shown by lake sediments in the mountain valleys and locally prominent shorelines (Ferrians and Nichols, 1965). Apparently the waters were impounded by a solid glacier dam in the Copper River canyon south of the quadrangle that was breached before 9,000 years ago.

Studies in the region also focused on geologic and hydrologic hazards. Hydrologic hazards (Post and Mayo, 1971) include flooding by high runoff, glacier outburst floods, and 
icings in winter. The sudden release of water stored within or adjacent to glaciers has damaged roads and bridges on Tazlina and Tsina Rivers and Sheep Creek near Valdez. Winter icings on the Klutina River have inundated the village of Copper Center and are common on the Copper River and some of its tributaries (Williams and Johnson, 1981).

Geologic hazards include the effects of permafrost, volcanic activity, and earthquakes. Permafrost is widespread north of the Tsina River in the Chugach Mountains (Ferrians and Nichols, 1965; Ferrians and others, 1969; Williams, 1970) and, in unconsolidated deposits, poses an engineering problem during construction. Descriptions of the engineering properties of the unconsolidated units in the Copper River Basin (Nichols and Yehle, 1969) and along the Richardson Highway in the Chugach Mountains (Coulter and Coulter, 1961, 1962) provided important information during construction of highways and public facilities in the region. Concerns with ground stability became paramount during construction of the Trans-Alaska Pipeline System in the 1970's. Disturbance of the thermal regime in fine-grained sediments, particularly the glaciolacustrine silt and clay that is common near the surface in much of the Copper River Basin (Ferrians, 1971), thaws the ice-rich permafrost, leading to differential settlement. As a result, the Trans-Alaska Pipeline was elevated over most of these sensitive deposits and is consistently buried for only the southernmost $69 \mathrm{~km}$ from near Ptarmigan to its terminus at Fort Liscum.

Mount Wrangell is the only active volcano in the Wrangell Mountains. The summit caldera includes three craters that have active fumaroles (Benson and Motyka, 1979), and ash darkens the summit snowfield from time to time. Personnel of the University of Alaska Geophysical Institute have been studying glacier-volcano interaction on Mount Wrangell since 1953 and have reported a major increase in heat flux at the summit since 1970 (Benson and Motyka, 1979); however, activity apparently has been limited to the caldera since pre-late Wisconsin time (Williams and Johnson, 1981). Pre-late Wisconsin lava flows and volcaniclastic debris flows from Mount Wrangell are interbedded with unconsolidated deposits in nearby areas of the Copper River Basin and extend as far west as Lower Tonsina and south as far as Chitina (Yehle and Nichols, 1980). A recurrence of larger eruptions such as these, although unlikely, could spread devastation beyond the Copper and Chitina Rivers, and showers of volcanic ash, depending on wind direction at the time, might extend over large areas of the Valdez quadrangle. The most likely hazards of a small eruption would be local flooding and mud flows that would be confined to canyons on the flanks of the volcano.

U.S. Geological Survey investigations in the Valdez quadrangle and throughout southern Alaska were accelerated in response to the 1964 Alaska earthquake, the epicenter of which was about $40 \mathrm{~km}$ west of the southwest corner of the quadrangle. Evaluations of the aftereffects of this extremely powerful tectonic event include detailed studies in the Port Valdez (Coulter and Migliaccio, 1966) and Copper River Basin (Ferrians, 1966) areas, as well as regional syntheses (for example, Case and others, 1966; Plafker, 1969). Ground-motion values for a Richter magnitude 8.5 earthquake were used to formulate design criteria for the TransAlaska Pipeline from Valdez to Willow Lake, and values for a Richter magnitude 7.0 earthquake were used from Willow Lake northward to the quadrangle boundary (Page and others, 1972). The potential earthquake hazards posed by activity on major faults in the region led to detailed studies of the Border Ranges fault (MacKevett and Plafker, 1974; Plafker, Nokleberg, and Lull, 1985) and the Contact fault system (Plafker and Lanphere, 1974; Winkler and Plafker, 1975, 1981; Plafker and others, 1977, 1986), as well as regional studies of major fault systems throughout southern Alaska (for example, Plafker and others, 1977). Conjunctive regional studies of the plutonic rocks of southern Alaska also were completed (Hudson, 1979, 1983).

In the early 1970's, thesis studies were carried out in the Tonsina area by graduate students at the University of Alaska. Hoffman (1974) described the geologic setting for the layered ultramafic and mafic rocks at Bernard Mountain, and Metz (1976) described blue-amphibole-bearing schistose rocks west of Chitina, the first discovery of blueschists in the quadrangle.

During the 1970's and 1980's, the U.S. Geological Survey conducted interdisciplinary mineral-resource assessments of several nearby $1^{\circ} \times 3^{\circ}$ quadrangles: the McCarthy quadrangle on the east (Singer and MacKevett, 1976; MacKevett, 1978); the Seward and Blying Sound quadrangles on the southwest (Tysdal and Case, 1979, 1982); the Cordova and Middleton Island quadrangles on the south (Winkler and Plafker, 1981, 1992; Goldfarb and others, in press); and the Anchorage quadrangle on the west (Madden-McGuire and others, in press; Winkler, in press). These investigations under the auspices of the Alaska Mineral Resources Assessment Program (AMRAP) provide detailed information on the geology and mineral resources of geologic terranes that extend directly into the Valdez quadrangle as well as a wealth of basic earth-science information.

For the AMRAP investigations summarized herein, a series of reports was prepared that provides information on the geology, geochemistry, geophysics, telegeology, and known and speculated mineral resources of the Valdez quadrangle (table 1). The reports provide multidisciplinary, contemporary mineral-resource information as potential input for land-use planning and minerals-policy development and as guidance for minerals exploration. The reports also enhance the geologic knowledge of a region that had received few recent earth-science investigations.

In the early 1980 's, a regional study of the potential for undiscovered mineral resources in the Chugach National Forest was completed (Jansons and others, 1984; Nelson and others, 1984). Additional geological mapping (Nelson and 
others, 1985) and geochemical sampling (Goldfarb and others, 1984) in the southern part of the Valdez quadrangle provide much better delineation and characterization of several areas that are likely to contain base-and preciousmetal resources in massive-sulfide and vein deposits. In the mid-1980's, multidisciplinary geophysical investigations of the deep crustal structure of south-central Alaska were conducted along the southern part of the TACT corridor. Detailed surface geologic studies were carried out in support of the geophysical studies (Plafker, Nokleberg, and Lull, 1985), including mapping of five 15-minute quadrangles in the Valdez quadrangle (Plafker, Lull, and others, 1989) and a variety of structural, geochemical, and isotopic studies near the transect. Plafker, Nokleberg, and Lull (1989) and Nokleberg and others (1989) described the lithologic and structural features and the tectonic evolution of the four lithostratigraphic terranes that make up the Valdez quadrangle.

\section{GEOCHEMICAL INVESTIGATIONS}

In a detailed study of massive-sulfide occurrences southeast of Port Valdez, Rose (1965) reported chemical analyses for about 18 sulfide-bearing rock samples and about 80 stream-sediment samples. The rock samples contained anomalous amounts of copper, gold, zinc, and silver, several of the stream-sediment samples contained anomalous amounts of copper, and two panned-concentrate samples contained visible gold. Jasper (1967) collected 102 streamsediment samples for chemical analysis and pannedconcentrate samples for microscopic examination from sites close to the Richardson Highway between Valdez and Tonsina and the Edgerton Highway between Lower Tonsina and Chitina. The resulting data indicate nothing of economic interest. Herreid (1970) conducted detailed stream-sediment, soil, and rock-chip sampling in the vicinity of the Spirit Mountain nickel-copper prospect and examined the prospect in detail. In the 1980's, the U.S. Bureau of Mines conducted regional investigations of mafic and ultramafic complexes along the Border Ranges fault in southern Alaska, collecting bulk samples that were concentrated and assayed for cobalt, copper, chromium, gold, nickel, palladium, platinum, and silver (Foley and Barker, 1985; Foley and others, 1987, 1989).

During the 1970's, 457 stream-sediment, 500 lake-sediment, and 1,205 water samples were collected in the Valdez quadrangle for the National Uranium Resource Evaluation (NURE) program of the U.S. Department of Energy (Sharp and Hill, 1978; D'Andrea and others, 1981; Los Alamos National Laboratory, 1983). Many sample sites were clustered in areas of easy access; remote parts of the quadrangle were not sampled nor were heavy-mineral-concentrate samples collected. A reconnaissance stream-sediment geochemical survey was conducted throughout the Valdez quadrangle in 1978 and 1979 as part of the AMRAP study. Chemical analyses for the composite stream-sediment and heavy-mineral-concentrate samples that were collected are reported in Miller and others (1982). In the early 1980's, streamsediment and concentrate samples were collected at an additional 98 sites along the southern edge of the Valdez quadrangle (Goldfarb and others, 1984). Sutley and others (1990) collected additional stream-sediment and heavymineral-concentrate samples in the vicinity of Bernard Mountain. The AMRAP and NURE geochemical data were evaluated by Goldfarb and others (in press), who included an extensive R-mode factor analysis of chemical associations, described 31 areas of geochemical anomalies in detail, and interpreted sources for the anomalous values.

Two-thirds of the anomalous areas defined by Goldfarb and others (in press) are within the Chugach terrane, which is dominated by greenschist-grade metasedimentary rocks. Anomalous concentrations of gold, silver, arsenic, and many base metals in both sediment and concentrate samples indicate a high geochemical favorability for the presence of mesothermal, precious- and base-metal-bearing quartz veins (Goldfarb and others, in press). The largest of these areas covers about $750 \mathrm{~km}^{2}$ between Columbia Glacier and the Lowe River and includes the Port Valdez mining district. Reports by Pickthorn (1982), Pickthorn and Silberman (1984), Goldfarb and others (1986), and Goldfarb (1989) describe the geologic setting and chemical and isotopic characteristics of mineral deposits within this area. Anomalies for iron, cobalt, nickel, and copper in many samples from the south-central margin of the Valdez quadrangle between Solomon Gulch and Schwan Glacier indicate the upstream presence of disseminated or massive sulfide occurrences. These volcanogenic occurrences are spatially associated with mafic volcanic rocks within the Chugach terrane (Winkler, Miller, MacKevett, and Holloway, 1981; Crowe and others, in press; Goldfarb and others, in press). Concentrate samples containing anomalous amounts of manganese characterize the area between Bench and Marshall Glaciers and the southeast corner of the quadrangle. The anomalies most likely are derived from erosion of recognized manganese enrichments in phyllite and schist of the Chugach terrane in upstream areas (Goldfarb and others, in press).

Stream-sediment samples containing consistently anomalous amounts of cobalt and copper and commonly anomalous amounts of silver, chromium, iron, nickel, lead, and zinc are derived from rocks of the Wrangellia terrane south of the Chitina River. The anomalies define geochemically favorable ground for (1) both disseminated and massive volcanogenic or Kennecott-type copper-sulfidedominant mineral occurrences associated with upper Paleozoic and Triassic mafic volcanic rocks and Triassic carbonate sedimentary rocks and (2) magmatic cobalt- and nickel-bearing sulfide minerals in ultramafic bodies. North of the Chitina River, samples from the Wrangellia terrane are anomalous in copper, boron, vanadium, antimony, barium, zinc, and molybdenum (Goldfarb and others, in press). Some 
of the anomalies reflect known volcanogenic copper occurrences; others may indicate the presence of weakly mineralized porphyry systems in Jurassic plutons of the Chitina Valley batholith (Winkler, Miller, MacKevett, and Holloway, 1981).

Silicified, pyrite-rich volcanic rocks of the Talkeetna Formation crop out at Heavenly Ridge in the northwestern part of the Valdez quadrangle, where they are intruded by numerous felsic plugs and dikes (Winkler, Miller, MacKevett, and Holloway, 1981). Several similar occurrences are nearby in the Anchorage quadrangle and at Willow Mountain along the Richardson Highway, both areas where felsic plutons have not been identified. According to Newberry (1986), the alteration is probably syngenetic with the volcanic activity.

A large region likely to contain chromite lenses in layered ultramafic and mafic rocks of the Peninsular terrane is defined around Bernard and Dust Creeks by stream sediments containing anomalous amounts of chromium, iron, nickel, magnesium, and vanadium. Samples collected along the Border Ranges fault between Barnette and Klanelneechena Creeks contain anomalous levels of a similar suite of elements as well as copper. A few samples containing anomalous amounts of gold, silver, and boron suggest that precious-metal-bearing occurrences may be present locally in drainages tributary to Klanelneechena Creek (Goldfarb and others, in press).

\section{GEOPHYSICAL INVESTIGATIONS}

An aeromagnetic survey was flown over the northern part of the Valdez quadrangle in 1954 and 1955 (Andreason and others, 1958) in connection with a topical study of the Copper River Basin. In 1978, an aeromagnetic survey was flown over the remainder of the quadrangle to provide regional data for the AMRAP study (U.S. Geological Survey, 1979). Prior interpretations of aeromagnetic maps to the northeast in the Nabesna quadrangle (Griscom, 1975), to the east in the McCarthy quadrangle (Case and MacKevett, 1976), to the northwest in the Talkeetna Mountains quadrangle (Csejtey and Griscom, 1978), and to the southwest in the Seward and Blying Sound quadrangles (Case and others, 1979) aided the interpretation of data in the Valdez quadrangle. For the survey of the Valdez quadrangle, Case, Burns, and Winkler (1986) spliced the contoured data sets of the two aeromagnetic surveys, provided measurements of magnetic susceptibilities for samples of the main rock units, interpreted the combined aeromagnetic maps in terms of the units causing geophysical anomalies, and illustrated five aeromagnetic profiles and interpetative cross sectional models. Burns (1982) made a detailed interpretation of aeromagnetic data over the northern Chugach Mountains in the northwestern part of the quadrangle. The most conspicuous aeromagnetic anomalies of the Valdez quadrangle, attaining amplitudes of several thousand gammas, are over the layered mafic rocks of the Nelchina River Gabbronorite (Plafker, Nokleberg, and Lull, 1989). Locally, these rocks contain 10-15 percent modal magnetite and ilmenite. This aeromagnetic feature was called the Northern Chugach Mountains anomaly by Andreason and others (1964). It also has a relative positive gravity of 20-30 milligals (mGals) (Barnes, 1977). Five north-south magnetic profiles modeled across the gabbronorite (Burns, 1982) indicate a general northerly dip to the body and a steep truncation on its south margin. The aeromagnetic anomaly in the northern Chugach Mountains extends discontinuously westward across the Anchorage quadrangle to the vicinity of Palmer, where it turns southward (Burns and others, 1991) to connect with the Knik Arm anomaly of Grantz and others (1963). Fisher (1981) and Case, Fisher, and others (1986) have proposed linkage with a similar aeromagnetic anomaly extending southwest along the continental shelf and the west sides of Afognak and Kodiak Islands, where layered mafic plutonic rocks are exposed. If the inference is correct, this gabbroic body constitutes a major geologic feature of southern Alaska. Layered rocks of the Tonsina ultramafic-mafic sequence of Plafker, Nokleberg, and Lull (1989) and the fault-bounded layered mafic body on Klanelneechena Creek also have pronounced positive magnetic expressions; the Tonsina ultramafic-mafic sequence coincides with a general gravity high of about +20 to $+30 \mathrm{mGals}$ (Barnes, 1977).

In the northeastern part of the quadrangle, the magnetic anomaly field is heterogeneous and includes numerous highamplitude, steep-gradient, positive anomalies separated by low-amplitude negative anomalies (Case, Burns, and Winkler, 1986). Most of the positive anomalies probably are of composite origin and are caused by volcanic rocks of the Wrangell Lava and by Jurassic intermediate to mafic plutons of the Chitina Valley batholith. Some anomalies are caused by the Triassic Nikolai Greenstone, gabbroic plutons mapped as part of the Skolai Group (Winkler, Silberman, and others, 1981), and mafic metaplutonic and ultramafic rocks in the Haley Creek metamorphic assemblage of Plafker, Nokleberg, and Lull (1989). In the northwestern part of the Valdez quadrangle, isolated high-amplitude anomalies are over volcanic rocks of the Talkeetna Formation, similar to the main area of Talkeetna outcrops in the Anchorage quadrangle to the west (Burns and others, 1991). South of the Border Ranges fault, magnetic anomalies are few, small, and subdued, indicating a great depth to magnetic basement (Case, Burns, and Winkler, 1986). The few small positive anomalies are caused by mafic volcanic rocks in the McHugh Complex and the Valdez and Orca Groups. The gravity field is equally subdued, with a broad low on the order of $-20 \mathrm{mGals}$ between Klutina Lake and Chitina (Barnes, 1977), where rocks of the Valdez Group are intruded by abundant felsic dikes and sills. 
In the mid-1980's, geophysical investigations of the deep crustal structure of southern Alaska were conducted along the southern part of the Trans-Alaska Crustal Transect (Page and others, 1986). The combined geologic and geophysical data indicate that the upper crust beneath the Valdez quadrangle consists of rootless sheets less than $10 \mathrm{~km}$ thick formed of rocks of the Chugach, Wrangellia, and Peninsular terranes. The sheets are bounded on the south by northdipping thrust faults that sole into shallow, almost horizontal low-velocity zones (Page and others, 1986). Fuis and Plafker (1991) inferred that undulating reflectors in the upper crust at depths between about 6 and $10 \mathrm{~km}$ are tonalitic plutons, which fed swarms of dikes and sills that are exposed at the surface directly above (Winkler, Silberman, and others, 1981). Subparallel, north-dipping, strong seismic reflectors between about 8 and $24 \mathrm{~km}$ depth in the Chugach Mountains have been interpreted (Fuis and Plafker, 1991) as underplated oceanic crust and possibly upper mantle. Studies of earthquake seismicity (Page and others, 1989), seismic reflection (Fisher and others, 1989) and refraction (Fuis and others, 1991), and potential fields (Campbell, 1991) yielded abundant data on the deep crust that show a gently inclined north-dipping Benioff zone deepening from about $25 \mathrm{~km}$ near the southern boundary of the quadrangle to about $40 \mathrm{~km}$ near Tonsina. $P$-wave velocities are about $5.9-7.4 \mathrm{~km} / \mathrm{sec}$ in the lower crust beneath the Chugach Mountains and about $7.8 \mathrm{~km} / \mathrm{sec}$ in the upper mantle (Fuis and others, 1991).

\section{GEOLOGIC AND TECTONIC SUMMARY}

The Valdez quadrangle encompasses four distinctive fault-bounded lithotectonic terranes of contrasting stratigraphy, age, and structural style (Winkler, Silberman, and others, 1981; Plafker, Nokleberg, and Lull, 1989). From north to south, they are the Wrangellia, Peninsular, Chugach, and Prince William terranes (figs. 2, 3) (Jones and others, 1987). Rocks of the Yakutat terrane (outboard of the other four to the south) are not exposed in the Valdez quadrangle, but impingement of the Yakutat terrane against and beneath the continental margin is manifested by arc volcanism in the Wrangell Mountains (Plafker, 1987).

\section{Wrangellia Terrane}

The Wrangellia terrane occupies the northeastern part of the Valdez quadrangle and is bounded on the south by the Border Ranges fault and on the west by the Taral fault (fig. 2). The Taral fault is not exposed north of the Chitina River; its position beneath unconsolidated deposits of the Copper River Basin is inferred from aeromagnetic data (Case, Burns, and Winkler, 1986) to connect with the West Fork fault in the Gulkana quadrangle (Nokleberg and others, 1986). The Wrangellia terrane is divided into two distinct domains separated by the Chitina fault system (Gardner and others, 1986): (1) a southern domain consisting of penetratively deformed greenschist to lower amphibolite facies metasedimentary, metavolcanic, and metaplutonic rocks and (2) a northern domain consisting of the typical Triassic sequence of the Wrangellia terrane (hereinafter referred to as the type Wrangellia sequence or terrane) (Jones and others, 1977; see also, Plafker, Nokleberg, and Lull, 1989). Metamorphic rocks south of the Chitina fault system include Pennsylvanian and Jurassic metaplutonic rocks (Aleinikoff and others, 1988) and Permian and older metasedimentary and metavolcanic rocks of the southern Wrangellia terrane margin (Plafker, Nokleberg, and Lull, 1989). The metasedimentary rocks include marble containing diagnostic Early Pennsylvanian conodonts (Plafker, Harris, and Reed, 1985). Based on detailed work between the Richardson Highway and the Copper River and reconnaissance work in the Dadina River area, Plafker, Nokleberg, and Lull (1989) redefined these rocks as the Haley Creek metamorphic assemblage, including the Uranitina River metaplutonic unit and the Strelna Metamorphics. These rocks are penetratively deformed into elongate map patterns (Winkler, Silberman, and others, 1981; Plafker, Lull, and others, 1989) and contain zones of large ductile strike-slip shear of unknown sense (Pavlis and Crouse, 1989). They are similar in composition, however, to parts of the type Wrangellia sequence north of the fault. Locally, the southern Wrangellia terrane margin includes the Triassic Nikolai Greenstone and the Chitistone and Nizina Limestones, the most characteristic rocks of the type Wrangellia terrane north of the fault. Rocks north of the Chitina fault system include upper Paleozoic mafic volcaniclastic and flow rocks correlative with the Station Creek Formation of the Skolai Group (Smith and MacKevett, 1970). In nearby areas, these rocks and associated lithologically variable plutonic rocks define the Pennsylvanian and Early Permian Skolai magmatic arc that constitutes the basement sequence of the Wrangellia terrane (Bond, 1973; Richter and Jones, 1973; MacKevett, 1978; Plafker, Nokleberg, and Lull, 1989). The arc rocks are overlain successively by Lower Permian shallow-marine rocks (correlative with the Hasen Creek Formation; Smith and MacKevett, 1970), Middle and (or) Upper Triassic rift-fill tholeiitic basalt (the Nikolai Greenstone), and Upper Triassic and Lower Jurassic shallow-marine evaporitic, calcareous, and argillaceous strata (Chitistone and Nizina Limestones and McCarthy Formation). Late Jurassic tonalitic plutons of the Chitina Valley batholith (MacKevett, 1978) intrude both the type Wrangellia terrane and the southern Wrangellia terrane margin (Winkler, Silberman, and others, 1981); however, in the southern Wrangellia terrane margin, these plutons are more abundant, more mafic, and generally foliated, indicating a deeper level of exposure (Plafker, Nokleberg, and Lull, 1989). 

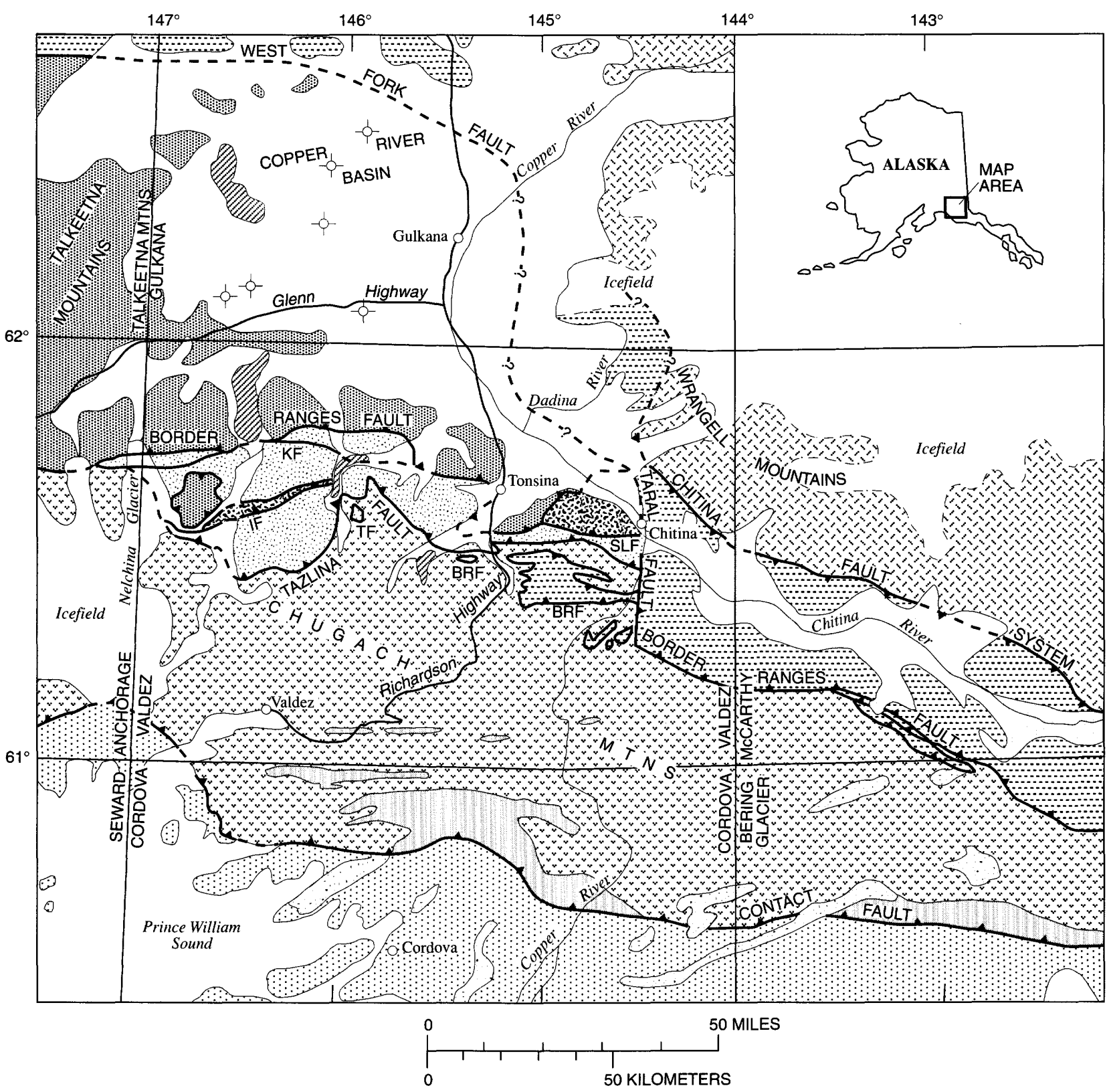

EXPLANATION

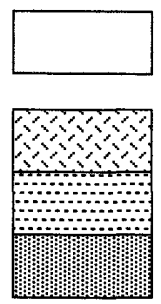

Surficial deposits (Quaternary)

Wrangellia terrane-Divided into:

Type Wrangellia terrane

Southern Wrangellia terrane margin

Peninsular terrane
Chugach terrane-Divided into: Valdez Group (Cretaceous) Consists of:

Metasedamentary rocks

Metabasalt

McHugh Complex (Mesozoic)

Schist of Liberty Creek

(Jurassic)

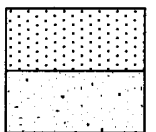

Prince William terrane Granitic rocks (Eocene)

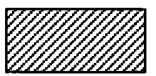

Lake

$-d$

Dry well

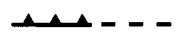

Fault, sawteeth on upper plate, dashed where queried or concealed 
Figure 2 (facing page). Generalized geology of the Valdez quadrangle including major geologic units and their lithostratigraphic terrane affinities, selected structural and geographic features, and the names of adjacent 1:250,000-scale quadrangles. BRF, Border Ranges fault; IF, Iceberg fault; KF, Klutina fault; SLF, Second Lake fault; TF, Tazlina fault. Modified from Plafker, Nokleberg, and Lull (1989).

Plutonic rocks of the Chitina Valley batholith and metaplutonic rocks of the Uranatina River metaplutonic unit are part of a belt of Late Jurassic plutons that extends at least from Chichagof Island in southeastern Alaska to Tonsina (Hudson, 1983). These plutons define the Chitina magmatic arc (Plafker, Nokleberg, and Lull, 1989); late stages of their intrusion overlap onset of major regional orogeny in the Late Jurassic that culminated in the Early Cretaceous with the initial development of the Chitina and Border Ranges fault systems (MacKevett and Plafker, 1974; MacKevett, 1978).

In the Valdez quadrangle, synorogenic deposits include very thick and coarse, local wedges of the nonmarine Middle or Upper Jurassic Kotsina Conglomerate that are overlain with probable unconformity by Upper Jurassic(?) and Lower Cretaceous marginal-marine sedimentary rocks. These Neocomian and older(?) rocks include unnamed rocks in the Cheshnina and Chetaslina River canyons (Grantz and others, 1966) and the Berg Creek Formation (MacKevett and others, 1978).

The Chitina fault is completely concealed in the Valdez quadrangle but is well exposed to the east in the McCarthy quadrangle (MacKevett, 1978; Gardner and others, 1986). Apparently, Early Cretaceous uplift between the southwestdipping thrust faults and related folds of the Chitina fault system and the Border Ranges fault has exposed deeper levels of the basement sequence for the Wrangellia terrane in the southern Wrangellia terrane margin. Furthermore, the position of deep-seated Jurassic plutons at the Border Ranges fault indicates that a substantial segment of the southern Wrangellia terrane margin has been tectonically removed since the Late Jurassic (MacKevett, 1978; Plafker, Nokleberg, and Lull, 1989).

\section{Peninsular Terrane}

The Peninsular terrane occupies the north-central and northwestern parts of the Valdez quadrangle and is bounded on the south by the Border Ranges fault and on the east by the Taral fault. The Peninsular terrane includes both intrusive and extrusive phases of a Late Triassic(?) through Middle Jurassic intraoceanic magmatic arc (Barker and Grantz, 1982; Burns, 1985) and Cretaceous marine sedimentary strata deposited in fore-arc basins. To the west in the Anchorage quadrangle, a Middle Jurassic marine fore-arc sequence also is present. In the Valdez quadrangle, the extrusive phase of the arc is represented by the Talkeetna Formation and consists dominantly of bedded andesitic and basaltic tuff, tuff breccia, flow rocks, shallow intrusive rocks, and volcanogenic marine sedimentary rocks (Winkler, Silberman, and others, 1981). The Cretaceous rocks are represented by the Matanuska Formation, a transgressive marine sequence that deepened through time from shallow shoalwater deposition in its lower part to deposition on the distal reaches of a deep-sea fan in its upper part (Grantz, 1965).

The Peninsular terrane generally dips northward, thereby exposing deeper structural levels, the crystalline roots of the early Mesozoic Talkeetna magmatic arc, along its southern edge. The crystalline roots of the arc in the Valdez quadrangle are composed principally of layered gabbronorite, peridotite, and dunite, the Border Ranges ultramafic-mafic assemblage of Plafker, Nokleberg, and Lull (1989) (or the Border Ranges ultramafic and mafic complex of Burns, 1985). The assemblage has two subdivisions: the deeper level Tonsina ultramafic-mafic sequence (Plafker, Nokleberg, and Lull, 1989; see also Coleman and Burns, 1985, and DeBari and Coleman, 1989), consisting of a distinctive cumulate sequence of dunite, peridotite, and garnet-bearing gabbro, and the shallower level Nelchina River Gabbronorite (Plafker, Nokleberg, and Lull, 1989; Burns, in press). The Tonsina ultramafic-mafic sequence is exposed only in low hills and stream cuts from just west of the Richardson Highway to the east bank of the Copper River (Winkler, Silberman, and others, 1981). Probable correlative ultramafic-mafic sequences, the Wolverine Complex of Carden and Decker (1977) and Eklutna Complex of Burns (1985), are present along the northern margin of the Border Ranges fault system to the west in the Anchorage quadrangle (Clark, 1972a; Burns, 1985; Winkler, 1990). The Nelchina River Gabbronorite is widely exposed from just east of the Richardson Highway westward along the southern margin of the Peninsular terrane to the vicinity of Palmer in the Anchorage quadrangle (Winkler, Miller, Silberman, and others, 1981; Winkler, Silberman, and others, 1981; Burns, 1985; Winkler, 1990). The Nelchina River Gabbronorite and its cover rocks, the Talkeetna Formation, are locally exposed and produce prominent, almost continuous geophysical anomalies southwestward to the Kodiak Island area and the Alaska Peninsula, an additional $600 \mathrm{~km}$, that define the full extent of the Talkeetna arc.

West of the Valdez quadrangle, the southern margin of the Peninsular terrane includes a multiply deformed metamorphic assemblage of probable Paleozoic protoliths, the informally named Knik River schist terrane (Carden and Decker, 1977), which was basement for part of the Talkeetna 


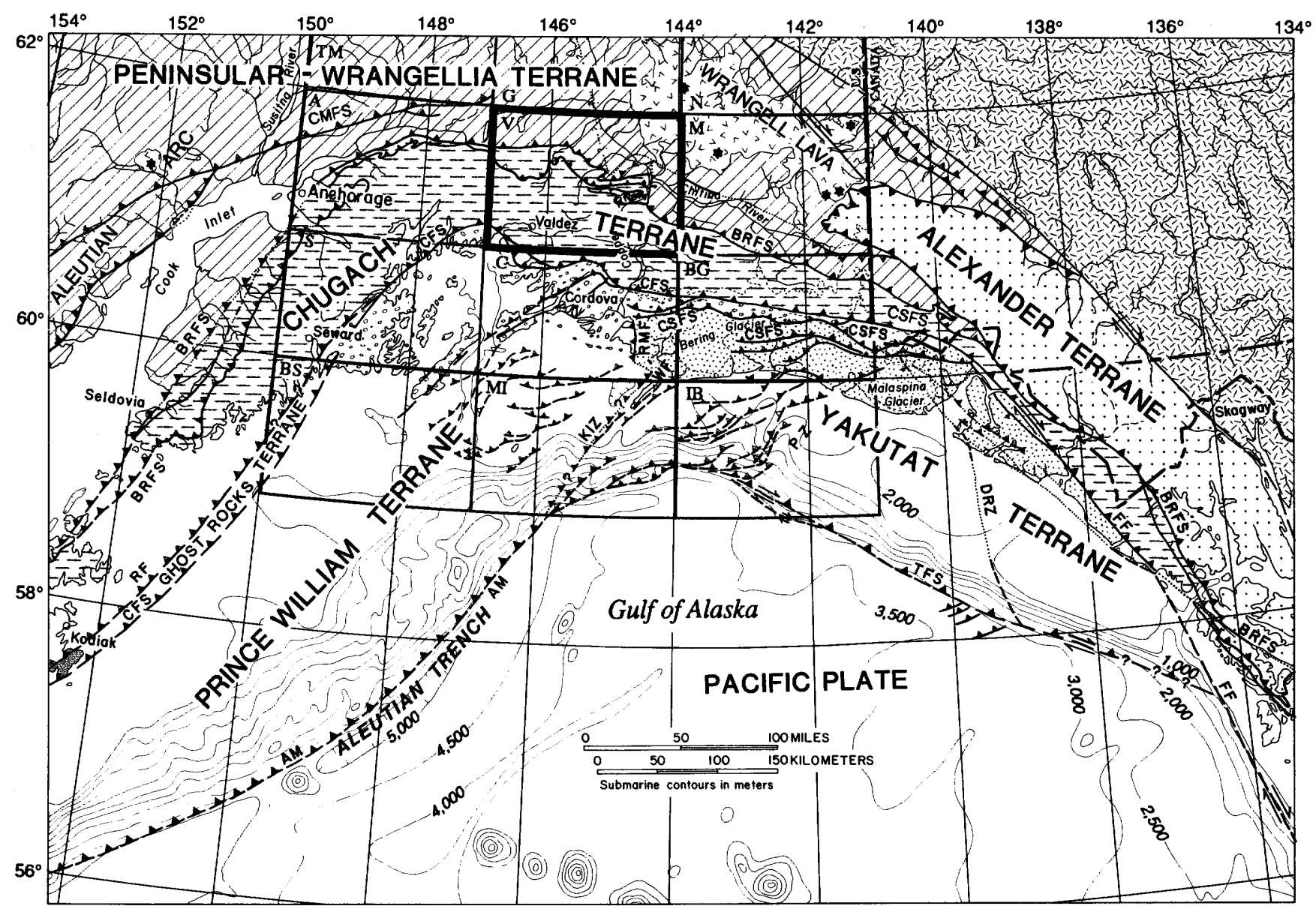

EXPLANATION

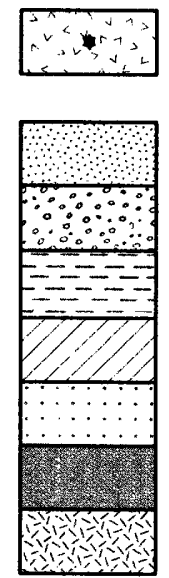

Cenozoic volcanic rocks-Star shows

location of andesitic volcano

Terranes

Yakutat

Prince William

Chugach

Peninsular-Wrangellia (composite)

Alexander

Ghost Rocks

Undifferentiated

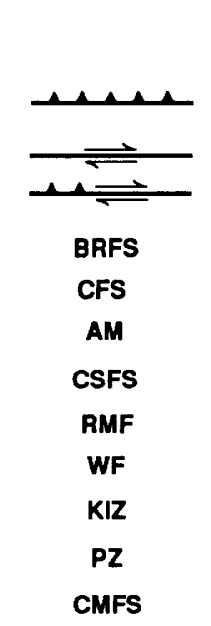

FF
Fault-Dashed where approximately located, dotted where concealed, queried where inferred

Thrust-Sawteeth on upper plate, Open teeth indicate major terrane or plate boundary

Strike slip-Arrows indicate relative horizontal motion Oblique thrust-Sawteeth on upper plate, arrows indicate
relative horizontal motion

Border Ranges fault system

Contact fault system

Aleutian megathrust

Chugach-St.Elias fault system

Ragged Mountain fault

Wingham fault

Kayak Island zone

Pamplona zone

Castle Mountain fault system

Fairweather fault

Figure 3. Geologic terranes of the southern Alaska region. Selected faults and boundaries of $1^{\circ} \times 3^{\circ}$ quadrangles are also shown. A, Anchorage; BG, Bering Glacier; BS, Blying Sound; C, Cordova; G, Gulkana; IB, Icy Bay; M, McCarthy; MI, Middleton Island; N, Nabesna; S, Seward; TM, Talkeetna Mountains; V, Valdez (heavy outline). Modified from Plafker (1987). 
arc (Pavlis, 1983). Near Anchorage, carbonate rocks in the assemblage contain Permian Tethyian fusulinids (Clark, 1972b). The basement assemblage, and Early and Middle Jurassic plutons that intrude it, contains anastomosing zones as wide as a kilometer of distributed ductile and brittle shear of unknown sense that Pavlis (1982) related to Early Cretaceous underthrusting on the Border Ranges fault.

The bedded and intrusive sequences of the Wrangellia and the Peninsular terranes differ in several characteristics (Plafker, Nokleberg, and Lull, 1989). The Peninsular terrane lacks the distinctive Middle Triassic to Lower Jurassic riftfill basalt and intertidal to shallow-marine sedimentary sequence of the Wrangellia terrane, and the Wrangellia terrane lacks the characteristic Late Triassic and Early Jurassic arc-related volcaniclastic and plutonic rocks of the Talkeetna arc. The intrusive histories of the two terranes contrast markedly as well; the distinctive Late Jurassic tonalitic plutons of the Wrangellia terrane and the Early to Middle Jurassic ultramafic-mafic suite of the southern Peninsular terrane both terminate abruptly at the Taral fault, the terrane boundary (Winkler, Silberman, and others, 1981).

Although the Wrangellia and Peninsular terranes differ in detail in the geology of their basement rocks, their intrusive sequences, and their bedded cover rocks, they apparently have been juxtaposed since at least the Middle Jurassic. Middle Jurassic and younger clastic sections exposed in the southwestern Wrangell Mountains and the Nelchina area of the western part of Copper River Basin are probably overlap assemblages (Csejtey and others, 1978). Plafker, Nokleberg, and Lull (1989) suggested that the abrupt termination of the Talkeetna arc along the Taral fault may have originated during a total of $600-1,000 \mathrm{~km}$ of sinistral strike-slip offset that truncated a margin of the Wrangellia terrane in British Columbia where parts of the Queen Charlotte and Vancouver Islands are composed of coeval arc rocks. During the larger dislocation, about $40 \mathrm{~km}$ of relative overthrusting occurred along the Taral fault to juxtapose a flap of the Wrangellia terrane over the Peninsular terrane (Nokleberg and others, 1989). If this reconstruction is correct, then the Talkeetna Formation and correlative rocks in British Columbia also constitute an overlap assemblage that linked the Wrangellia and Peninsular terranes by Late Triassic time (Plafker, Nokleberg, and Lull, 1989). Furthermore, the occurrence in both terranes of coeval Permian carbonate rocks suggests that their amalgamation may have occurred even earlier during the late Paleozoic.

The large sinistral displacement between the Wrangellia and Peninsular terranes must have occurred between the Late Jurassic and middle Early Cretaceous because Late Jurassic plutons are sheared but overlapping Valanginian to Hauterivian sedimentary rocks, the Berg Creek Formation and
Nelchina Limestone, respectively, are apparently unaffected. The displacement also must have occurred prior to suturing of the amalgamated Wrangellia and Peninsular terranes (Talkeetna superterrane of Csejtey and St. Aubin, 1981) to North America by the mid-Cretaceous.

\section{Chugach Terrane}

The Chugach terrane (Berg and others, 1972) occupies most of the southern half of the Valdez quadrangle; it is the central part of a continuous belt of accreted deep-marine sedimentary and mafic volcanic rocks approximately $2,000 \mathrm{~km}$ long and $60-100 \mathrm{~km}$ wide in the coastal mountains of southern Alaska (Plafker and others, 1977). From north to south, the Chugach terrane consists of three major fault-bounded sequences: (1) Jurassic or older greenschist- and transitional blueschist-facies rocks; (2) Upper Triassic to mid-Cretaceous polygenetic broken formation and melange of the McHugh Complex; and (3) Upper Cretaceous volcaniclastic flysch and oceanic basaltic rocks of the Valdez Group, which comprise the major part of the terrane in the quadrangle (Winkler, Silberman, and others, 1981). Rocks of the Chugach terrane record intermittent accretion and deformation beginning in the Early Jurassic and continuing into the latest Cretaceous or earliest Tertiary. The rocks are variably metamorphosed: rocks of the prehnite-pumpellyite, greenschist, blueschist, and lowest amphibolite facies are present, but rocks of the lower greenschist facies are the most widespread. The terrane was extensively intruded and thermally metamorphosed by plutons and dikes about $50 \mathrm{Ma}$.

Along its northern margin, the Chugach terrane is juxtaposed against the Wrangellia and Peninsular terranes along the Border Ranges fault system. In different areas of the quadrangle, the schist of Liberty Creek, the McHugh Complex, or the Valdez Group are juxtaposed against the northern terranes. At its southern margin, the Chugach terrane is juxtaposed against the Paleogene sequence of the Prince William terrane along the Contact fault.

The Border Ranges fault, as mapped in the Valdez quadrangle, is a composite feature. According to MacKevett and Plafker (1974), it originated as a subduction thrust along the trailing edge of a microcontinent (including the Wrangellia and Peninsular terranes) that collided with the North American continental margin in mid-Cretaceous time (Csejtey and others, 1982; Monger and others, 1982; Pavlis, 1982). Subduction-related Early(?) Jurassic metamorphism of the schist of Liberty Creek was attributed by Nokleberg and others (1989) to an earliest episode of subduction under an "unknown backstop" to the north along a proto-Border Ranges fault. Alternatively, Roeske (1986) suggested that 
the schist formed in a distant subduction zone and was distributed subsequently along the Border Ranges fault by strike-slip displacement. Vestiges of this contact are present as near-vertical broad shear zones in ultramafic rocks of the Tonsina ultramafic-mafic sequence along the Border Ranges fault between the Second Lake and Taral faults. In the central part of the Valdez quadrangle, belts of the McHugh Complex apparently were accreted successively beneath the Peninsular terrane along the Border Ranges, Klutina, and Iceberg faults, apparently principally in the Late Jurassic and Early Cretaceous but possibly beginning as early as the Late Triassic or Early Jurassic (Winkler, Silberman, and others, 1981). The main episodes of melange formation are roughly coeval with successive magmatic events in the adjacent Talkeetna, Chitina, and Chisana arcs (Plafker, Nokleberg, and Lull, 1989). Syntectonic intrusion of Late Jurassic plutons of the Uranatina River metaplutonic unit in the Valdez quadrangle (Pavlis and Crouse, 1989) and Early Cretaceous tonalite-trondhjemite plutons in the Anchorage quadrangle (Pavlis and others, 1988) into the Border Ranges fault zone have been inferred to date episodes of strike-slip and thrust activity along the Border Ranges and related faults. Accretion of the Valdez Group in the latest Cretaceous or earliest Tertiary beneath both the Peninsular and Wrangellia terranes reactivated the Border Ranges fault as a megathrust. Vestiges of this contact are preserved beneath several klippen consisting of rocks of the southern Wrangellia terrane margin between Tonsina Lake and the Taral fault. The sinuous trace of the Border Ranges fault between the Copper and Tonsina Rivers results from folding and faulting of the thrust plate during accretion of terranes to the south along the Contact fault (Nokleberg and others, 1989). Much of the present trace of the Border Ranges fault in the Valdez and adjacent quadrangles is steeply dipping to vertical and resulted from Eocene reactivation of the system as an oblique-slip boundary (Little and Naeser, 1989).

The schist of Liberty Creek forms an outcrop belt $28 \mathrm{~km}$ long and $13 \mathrm{~km}$ wide along the northern margin of the Chugach terrane between Dust Creek and the Copper River (Winkler, Silberman, and others, 1981; Plafker, Lull, and others, 1989). The unit consists of greenschist and minor crossite-bearing blueschist containing rare lawsonite. The unit is intensely ductilely deformed, and its original stratigraphic thickness is unknown (Nokleberg and others, 1989). Its structural thickness is at least $5 \mathrm{~km}$. In the two places where it is exposed, the northern contact of the schist of Liberty Creek is marked by a broad, almost vertical shear zone of schistose serpentine and strongly deformed ultramafic rocks of the Tonsina ultramafic-mafic sequence (Plafker, Lull, and others, 1989). Along the southern boundary of the unit, the schist of Liberty Creek is juxtaposed against the $\mathrm{McHugh}$ Complex along an east-west-trending, almost vertical zone of strongly sheared country rocks, serpentinite, pyroxenite, and gabbro. The southern boundary of this zone is the Second Lake fault of Metz (1976). The lithology, relict textures, and geochemistry of the schist of Liberty Creek indicate that it is an oceanic assemblage of basalt flow rocks, breccia, tuff, and minor argillaceous and calcareous sedimentary rocks. Its protolith age is unknown, but its position in the accretionary complex indicates only that it likely is older than the less metamorphosed Upper Triassic to midCretaceous McHugh Complex against which it is juxtaposed. Plafker, Nokleberg, and Lull (1989) correlated the schist of Liberty Creek with dated blueschist and greenschist of the schist of Iceberg Lake in the western part of the Valdez quadrangle (Winkler, Miller, Case, and others, 1981). The schistose rocks near Iceberg Lake have Early to Middle Jurassic metamorphic ages (Sisson and Onstott, 1986; Plafker, Nokleberg, and Lull, 1989) and are in close association with paleontologically dated Upper Triassic oceanic rocks along the south side of the Border Ranges fault (Winkler, Silberman, and others, 1981). This association may indicate that the schistose rocks are a more deeply subducted part of the Upper Triassic oceanic assemblage (Plafker, Nokleberg, and Lull, 1989). The metamorphic age of the schist of Liberty Creek has been difficult to determine because of its very fine grain size. The Early Cretaceous $\mathrm{K}$-Ar ages (Winkler, Silberman, and others, 1981; Plafker, Nokleberg, and Lull, 1989) were probably reset, perhaps during accretion of the McHugh Complex to the south.

The McHugh Complex crops out in an irregular belt 3-37 $\mathrm{km}$ wide between the Border Ranges or Second Lake fault on the north, the Tazlina fault on the south, and the Taral fault on the east (Winkler, Silberman, and others, 1981; Plafker, Lull, and others, 1989). The McHugh Complex consists of pervasively disrupted and regionally metamorphosed broken formation and melange. Its maximum structural thickness is estimated to be about $20 \mathrm{~km}$ (Plafker, Nokleberg, and Lull, 1989). The broken formation originally was mainly tholeiitic basalt and related fragmental volcanic rocks, argillite or tuffaceous argillite, radiolarian chert, argillaceous siltstone and sandstone, and carbonate rocks. The lithology and geochemistry of the McHugh indicates it originated as an assemblage of oceanic volcanic rocks and pelagic sediments mixed with lesser amounts of siliciclastic sediments derived from an active continental arc (Plafker, Nokleberg, and Lull, 1989). Stratal disruption in the McHugh records a complex history of superimposed processes. Wispy intercalations and disharmonic folding record either submarine slumping or tectonic deformation of unlithified sediments, or both. Postconsolidation brittle disruption is pervasive and randomly oriented and varies in scale from microscopic fractures to large-scale mixing of rock types in complex fault networks. Broad zones of intense faulting lack any stratal continuity, and widespread faulting of unknown offset has juxtaposed contrasting rocks. Disrupted brittle phacoids at all scales in sheared argillite and tuff impart a characteristic blocks-in-matrix appearance to these melangelike parts of the unit. Large, coherent, exotic blocks of layered gabbro and other plutonic rocks were derived from the Peninsular or Wrangellia ter- 
ranes. The roughly circular klippe more than $10 \mathrm{~km}$ in circumference that occupies much of the drainage of Klanelneechena Creek between Tazlina and Nelchina Glaciers may be the largest of these exotic blocks derived from the microcontinental block to the north; however, several blocks of mafic plutonic rocks as large as $1 \mathrm{~km}$ are included in McHugh melange between the Border Ranges and Klutina faults. Large, exotic blocks of schistose rocks and marble also are present in the McHugh (Winkler, Miller, and Case, 1981; Winkler, Silberman, and others, 1981). The schist of Iceberg Lake forms a discrete faulted slab $40 \mathrm{~km}$ long and as wide as $4 \mathrm{~km}$ enclosed within melange marked by conspicuous elongated aligned blocks of marble as long as $2 \mathrm{~km}$; other smaller blocks of schist and marble are particularly conspicuous along the Iceberg and Klutina faults.

The best age for the McHugh Complex is provided by radiolarians, which are relatively common in chert in the melange matrix. In the western part of the Valdez quadrangle, the McHugh contains radiolarian assemblages of Late Triassic to mid-Cretaceous ages, the inferred depositional age span for the unit (Winkler, Silberman, and others, 1981). In general, the older samples are near the northern margin of the unit, and the youngest are near the southern margin. This age distribution is interpreted to indicate progressive accretion of slices of the McHugh Complex from north to south, and the structural style is interpreted to indicate disruption at a convergent plate margin. The age of these accretionary episodes is not known, but accretion must have been completed before accretion of the Upper Cretaceous Valdez Group that is outboard (south) of the McHugh.

The Valdez Group crops out in a belt more than $50 \mathrm{~km}$ wide that encompasses the crest of the Chugach Mountains. The Valdez is emplaced beneath rocks of the McHugh Complex along the Tazlina fault, a broadly folded thrust that dips moderately to the north (Winkler, Silberman, and others, 1981). The Tazlina fault occupies a comparable structural position to the Eagle River fault in the Anchorage quadrangle (Clark, 1972b; Winkler, 1990). Immediately beneath the Tazlina fault, surfaces of intense deformation in the Valdez are defined by isoclines and by metasandstone boudins that are elongated subparallel with the main fault surface. Rocks of the overlying McHugh Complex do not show a similar increase in deformation above the fault. Between Tonsina Lake and the Taral fault, the Valdez is surmounted by a thin, folded and faulted thrust sheet and outlying klippen of rocks of the southern Wrangellia terrane margin (Plafker, Lull, and others, 1989). Maximum structural thickness of the sheet is estimated to be $1-2 \mathrm{~km}$. East of the Taral fault, the Valdez Group is separated from the southern Wrangellia terrane margin on the north by a steeply north dipping trace of the Border Ranges fault. The southern limit of the Valdez Group is the Contact fault along which rocks of the Prince William terrane are thrust relatively beneath the Chugach terrane (Plafker and others, 1977; Nokleberg and others, 1989).

The Valdez Group consists of a thick, monotonous sequence of strongly deformed volcanogenic flysch and subordinate tholeiitic basalt flows and tuffs. The rocks are foliated, tightly folded, and commonly overturned to the south, and they are imbricated along numerous steeply north dipping faults. The volcanic rocks are not widespread in the Valdez quadrangle but extend southward into the adjacent Cordova quadrangle where they are much more abundant (Winkler and Plafker, 1981, 1992). Although the volcanic rocks are rarely more than a few tens of meters thick, they persist for more than $20 \mathrm{~km}$ along strike and are conspicuous in a broad east-west zone from east of the Copper River to near Hogback Glacier (Winkler, Silberman, and others, 1981). The aggregate stratigraphic thickness of the Valdez Group is not known, but at least several kilometers of strata are present; the structural thickness of the unit, based on geophysical data, is slightly less than $20 \mathrm{~km}$ (Plafker, Nokleberg, and Lull, 1989).

In most places in the Valdez quadrangle, structural features of the Valdez Group contrast markedly with those in the McHugh Complex: the Valdez is characterized by penetrative fabrics that record two major deformational events (Nokleberg and others, 1989). The first event produced tight isoclinal folds and transposition of fold hinges and is manifested by a pervasive planar or slaty cleavage that is generally parallel with bedding. This event is related to accretion of the Valdez Group against the continental margin and resulted in a series of imbricated coherent stratigraphic sequences bounded by shear zones or thrusts and only local preservation of fold hinges. The age of the first event is not constrained well but is believed to be latest Cretaceous to earliest Tertiary, prior to accretion of the Prince William terrane along the southern margin of the Chugach terrane. Underplating of a structural thickness of almost $20 \mathrm{~km}$ of the Valdez Group resulted in vertical uplift along the Border Ranges fault sufficient to expose the deepest metamorphosed levels of the accretionary prism by no later than 50 million years ago. At least $3 \mathrm{~km}$ of uplift within 15 million years of deposition of the Valdez Group probably occurred to the west in the Anchorage quadrangle (Little and Naeser, 1989). The second deformational event produced upright, open to tight folding of earlier structures and is manifested by one or more generations of crenulation cleavage in pelitic rocks, generally at high angles to earlier planar cleavage. At deeper structural levels, this second event produced intense ductile deformation and flattening. The second event probably is related to regional metamorphism and intrusion of plutons and dikes into the southern part of the Chugach terrane in the middle Eocene and again in the Oligocene, concurrent with deformation and intrusion in the Prince William terrane to the south.

Although internal primary sedimentary structures are well preserved in many of the coarser grained sedimentary rocks, the Valdez Group is regionally metamorphosed to lower greenschist facies. Fluid inclusion studies of metamorphic segregation veins near Tiekel indicate minimum temperatures of metamorphism of $230^{\circ} \mathrm{C}-300^{\circ} \mathrm{C}$ (Sisson and others, 1989); crosscutting quartz veins near Valdez have 
minimum trapping temperatures of $210^{\circ} \mathrm{C}-280^{\circ} \mathrm{C}$ and minimum trapping pressures of $1.5 \mathrm{kbar}$ (Goldfarb and others, 1986). Metamorphic grade increases "along strike to the southeast and culminates in the adjacent Bering Glacier quadrangle in a schist and gneiss crystalline complex containing sillimanite-grade migmatitic rocks (Hudson and Plafker, 1982). The metamorphic grade decreases westward to lowermost greenschist facies in the adjacent Anchorage quadrangle (Winkler, 1990). Superimposition of progressive metamorphism across regional structural trends within the Valdez Group indicates that metamorphism occurred after deformation and accretion against the continental margin. A minimum age for metamorphism of the Valdez Group is given by $\mathrm{K}-\mathrm{Ar}$ ages of $53.5-47.6 \pm 1.6 \mathrm{Ma}$ (Winkler and Plafker, 1981; Winkler, Silberman, and others, 1981). The higher grade metamorphic rocks represent deeply buried parts of the accretionary prism, and their development is believed to be related to emplacement of early Eocene anatectic granitic plutons in the region (Hudson and others, 1979) that culminated about $52 \pm 3 \mathrm{Ma}$.

The voluminous flysch of the Valdez Group probably accumulated in a continental-margin trench adjacent to an Andean-type arc (Monger and others, 1982; Nilsen and Zuffa, 1982; Plafker, Nokleberg, and Lull, 1989). Regional petrologic and sedimentologic data (Hollister, 1979; Zuffa and others, 1980; Nilsen and Zuffa, 1982; Dumoulin, 1987) indicate that the bulk of this sediment was derived from an evolved arc in the region of southeastern Alaska and coastal British Columbia, transported northwestward along the continental margin, and deposited as elongated fans mostly within a marginal trench. The mafic volcanic rocks of the Valdez Group are interpreted to represent oceanic crust upon which the clastic materials were deposited (Plafker, Nokleberg, and Lull, 1989; Lull and Plafker, 1990).

\section{Prince William Terrane}

In the southwest corner of the Valdez quadrangle, the Chugach terrane is separated from the Prince William terrane by the steeply north-dipping Contact fault (Plafker and others, 1977; Winkler, Silberman, and others, 1981). The fault trace in the Valdez quadrangle is a small part of a major early Tertiary terrane boundary that extends from near Mount Saint Elias to the continental shelf south of Kodiak Island (Plafker and others, 1977, 1986). The Prince William terrane consists primarily of the very thick and complexly deformed Orca Group, an accreted deep-sea fan complex interbedded with tholeiitic basalt and minor pelagic deposits (Winkler, 1976). Lenses of conglomerate in the Orca in the Sawmill Bay area are thought to represent feeder channels that distributed finer grained sediment to mid-fan depositional lobes where the great bulk of Orca flysch was depos- ited (Winkler and Tysdal, 1977). The sediment was derived mainly from the Coast Mountains of southeastern Alaska and British Columbia during the principal phase of plutonism and uplift in the Paleocene to middle Eocene (Hollister, 1979) and deposited as submarine fans on the Kula oceanic plate as it moved relatively northwestward. Interbedded basalt resulted from magma leakage as sea-floor spreading brought the Kula-Farallon Ridge near the continental margin. Widespread middle Eocene anatexis, intrusion, and low-pressure high-temperature metamorphism in the southern Wrangellia terrane margin and the Peninsular, Chugach, and Prince William terranes (Hudson and others, 1979; Winkler, Silberman, and others, 1981; Hudson and Plafker, 1982; Sisson and others, 1989) manifest subduction of the still active ridge in the eastern Gulf of Alaska. Intrusion of early middle Eocene plutons across both the Contact and Border Ranges faults indicates that there has been little or no younger horizontal displacement along the faults (Winkler and Plafker, 1981).

The stratigraphic thickness of the Orca Group in the region is unknown but may be as much as $6-10 \mathrm{~km}$ (Winkler and Plafker, 1981); the structural thickness is much greater, perhaps as much as $20 \mathrm{~km}$.

Successive accretion of wedges of flysch and basalt produced complex deformation of the Orca Group. Intense folding and faulting in both the upper and lower plates of the Contact fault resulted in parallel structures in both the Valdez and Orca Groups adjacent to the fault. At depth in the region, the Contact fault marks an abrupt change in deep crustal structure manifested by a sharp increase in seismic velocities (Fuis and Plafker, 1991).

The structural effects of underplating the Orca Group are not well understood in the Valdez quadrangle. They are complicated by the initial development of the southern Alaska orocline at about this time during rapid oblique subduction of Pacific oceanic crust beneath the Alaskan continental margin (Engebretson and others, 1986). Bends in the traces of the Border Ranges, Contact, and Castle Mountain faults, deflections in regional metamorphic and structural fabrics of Paleogene age in the Chugach and Prince William terranes, and paleomagnetic data indicating early Tertiary counterclockwise rotation of southwestern Alaska have been adduced as evidence for the orocline (summarized in Plafker, 1987, Little and Naeser, 1989, and Nokleberg and others, 1989). To the west in the Anchorage quadrangle, successive episodes of accretion in the Eocene are recorded by renewed normal offset on the Border Ranges fault and reverse-slip uplift on the Castle Mountain fault, followed by dextral oblique-slip of several tens of kilometers on the Border Ranges and Castle Mountain faults (Fuchs, 1980; Little, 1990). The obliquity of offset accommodated simultaneous accretionary thickening and oroclinal bending of the continental margin and created wrench faults, en echelon 
folds, fault-bend folds, and local pull-apart basins along the Border Ranges fault in the Anchorage quadrangle (Little, 1990), none of which are known in the Valdez quadrangle.

\section{Yakutat Terrane}

The Yakutat terrane is a composite terrane along the northern Gulf of Alaska continental margin that is composed mostly of relatively buoyant crustal rocks (Plafker, 1987). Rocks of the Yakutat terrane are not exposed in the Valdez quadrangle; in fact, the nearest exposures are approximately $65 \mathrm{~km}$ to the south in the Cordova quadrangle (Winkler and Plafker, 1981, 1992). The effects of the terrane's accretion are manifested, however, in the Valdez quadrangle by volcanism in the Wrangell Mountains and by renewed rapid uplift of the Chugach Mountains and deep erosion along the Border Ranges fault indicated by apatite cooling ages of 22-16 Ma for samples from the Chugach terrane (Little and Naeser, 1989). By Miocene time, the Yakutat terrane became coupled to the Pacific plate along the FairweatherQueen Charlotte dextral transform fault and was displaced northwestward to impinge against the continental margin between approximately Mount Saint Elias and the Copper River (Plafker, 1987). Northward displacement of the terrane is inferred to coincide roughly with the duration of arc volcanism in the Wrangell Mountains from about $20 \mathrm{Ma}$ to the present (Plafker, 1987). At least $2,000 \mathrm{~m}$ of andesitic flows, tephra, hypabyssal plugs and dikes, and minor volcanogenic sedimentary rocks in the northeast part of the Valdez quadrangle issued principally from the shield volcano of Mount Wrangell and may represent only a part of the volcanic pile that is Quaternary in age.

\section{POTENTIAL MINERAL RESOURCES}

Potentially significant undiscovered resources of precious, base, and ferrous metals may be present in several areas of the Valdez quadrangle near known occurrences (Winkler, Miller, MacKevett, and Holloway, 1981; Pickthorn and others, in press). North of the Border Ranges fault system, gold, silver, copper, zinc, and lead are present in disseminations and veins in late Paleozoic metavolcanic and metaplutonic rocks in several places in the southwestern Wrangell Mountains and the northern Chugach Mountains; in disseminations and veins in Triassic subaerial volcanic rocks near Elliott Creek in the Wrangell Mountains; in replacements and veins in Triassic and Jurassic marine sedimentary rocks near Elliott Creek in the Wrangell Mountains; and in veins and breccia zones in Jurassic volcanic rocks at Willow Mountain and Heavenly Ridge in the northern Chugach Mountains. Molybdenum is present in veins and disseminations in Jurassic plutonic rocks along the Chitina River west of the mouth of the Kuskulana River. East of the Copper River between Spirit Mountain and Summit Lake, ultramafic sills enriched in copper and nickel and minor silver, gold, and platinum-group elements intrude the late Paleozoic metamorphic sequence. Between the Richardson Highway and the Copper River at Bernard Mountain, Dust Mountain, and Sheep Hill, layered rocks in the Tonsina ultramafic-mafic sequence contain numerous lenses and disseminations of chromite and local enrichments in platinumgroup elements and gold. Near the head of Barnette Creek, ultramafic rocks in a broad shear zone along the southern boundary of the Nelchina River Gabbronorite also contain lenses of chromite, none of which are known to be large. In several places between Tazlina Lake and the western boundary of the Valdez quadrangle, layered rocks in the Nelchina River Gabbronorite contain elevated values of copper and nickel. Sulfide minerals have been noted locally and may be disseminated through much of the layered pluton; in places, their presence is marked by weak copper staining.

South of the Border Ranges fault system in the Chugach Mountains, gold, silver, copper, zinc, lead, and antimony are present in massive sulfide deposits and veins hosted by Cretaceous and Paleogene sedimentary and volcanic rocks and in veins hosted by felsic dikes and stocks that cut these sequences. Manganese is present in veins in schistose rocks along Liberty Creek northwest of Chitina. Placer gold may be present in small alluvial deposits underlain by rocks of the Valdez Group near known auriferous lodes and in alluvial sands within the canyons of the Copper, Bremner, Tasnuna, and Lowe Rivers and their tributaries.

\section{REFERENCES CITED}

Alaska Geological Society, 1970, Copper River Basin stratigraphic correlation sections: [Anchorage] Alaska Geological Society Stratigraphic Committee 1969-70, 2 sheets, vertical scale $1: 4,800$.

Aleinikoff, J.N., Plafker, George, and Nokleberg, W.J., 1988, Middle Pennsylvanian plutonic rocks along the southern margin of Wrangellia, in Galloway, J.P., and Hamilton, T.D., 1988, Geologic studies in Alaska by the U.S. Geological Survey during 1987: U.S. Geological Survey Circular 1016, p. 113.

Allen, H.T., 1887, Report of an expedition to the Copper, Tanana, and Koyukuk Rivers, in the territory of Alaska, in the year 1885: U.S. Government Printing Office, 172 p.

Andreason, G.E., Dempsey, W.J., Henderson, J.R., and Gilbert, F.P., 1958, Aeromagnetic map of the Copper River Basin, Alaska: U.S. Geological Survey Geophysical Investigations Map GP-156, 1 sheet, scale 1:125,000.

Andreason, G.E., Grantz, Arthur, Zietz, Isidore, and Barnes, D.F., 1964 , Geologic interpretation of magnetic and gravity data in the Copper River Basin, Alaska: U.S. Geological Survey Professional Paper 316-H, p. 135-153. 
Armstrong, A.K., and MacKevett, E.M., Jr., 1976, Relations between Triassic carbonate sabkhas and Kennecott-type copper deposits, Wrangell Mountains, in Cobb, E.H., ed., The United States Geological Survey in Alaska-Accomplishments during 1975: U.S. Geological Survey Circular 733, p. $50-51$.

1982, Stratigraphy and diagenetic history of the lower part of the Triassic Chitistone Limestone, Alaska: U.S. Geological Survey Professional Paper 1212-A, p. A1-A26.

Barker, Fred, and Grantz, Arthur, 1982, Talkeetna Formation in the southeastern Talkeetna Mountains, southern Alaska-An Early Jurassic andesitic island arc: Geological Society of America Abstracts with Programs, v. 14, no. 4, p. 147.

Barnes, D.F., 1977, Bouguer gravity map of Alaska: U.S. Geological Survey Geophysical Investigations Map GP-913, 1 sheet, scale $1: 2,500,000$.

Benson, C.S., and Motyka, R.J., 1979, Glacier-volcano interactions on Mt. Wrangell, Alaska: [Fairbanks] University of Alaska Geophysical Institute Annual Report 1977-78, p. 1-25.

Berg, H.C., Jones, D.L., and Richter, D.H., 1972, Gravina-Nutzotin belt-Tectonic significance of an upper Mesozoic sedimentary and volcanic sequence in southern and southeastern Alaska, in Geological Survey Research 1972: U.S. Geological Survey Professional Paper 800-D, p. D1-D24.

Bond, G.C., 1973, A late Paleozoic volcanic arc in the eastern Alaska Range: Journal of Geology, v. 81, p. 557-575.

Brooks, A.H., 1912, Gold deposits near Valdez: U.S. Geological Survey Bulletin 520, p. 108-130.

1914, The Alaska mining industry in 1913: U.S. Geological Survey Bulletin 592, p. 45-74.

Burns, L.E., 1982, Analysis of gravity and magnetic anomalies over a layered gabbro complex, Chugach Range, Alaska: U.S. Geological Survey Open-File Report 82-460, 96 p.

1985, The Border Ranges ultramafic and mafic complex, south-central Alaska-Cumulate fractionates of island arc volcanics: Canadian Journal of Earth Sciences, v. 22, p. 1020-1038.

in press, Geology of part of the Nelchina River Gabbronorite and associated rocks, south-central Alaska: U.S. Geological Survey Bulletin.

Burns, L.E., Case, J.E., and Winkler, G.R., in press, Aeromagnetic map and interpretation of the Anchorage quadrangle, southcentral Alaska: Alaska Division of Geological and Geophysical Surveys Geologic Report of Investigation, scale $1: 250,000$.

Campbell, D.L., 1991, Gravity and magnetic models of profiles near Richardson Highway, southern Alaska, in Guidebook to Field Trip T104: International Geological Congress, 28th, p. 69-74.

Capps, S.R., and Johnson, B.L., 1913, Mineral deposits of the Ellamar district: U.S. Geological Survey Bulletin 542-D, p. 86-124.

1915, The Ellamar district, Alaska: U.S. Geological Survey Bulletin 605, 125 p.

Carden, J.R., and Decker, J.E., 1977, Tectonic significance of the Knik River schist terrane, south-central Alaska, in Short notes on Alaskan geology-1977: Alaska Division of Geological and Geophysical Surveys Geologic Report 55, p. 7-9.

Case, J.E., Barnes, D.F., Plafker, George, and Robbins, S.L., 1966, Gravity survey and regional geology of the Prince William Sound epicentral region, in The Alaska earthquake, March 27, 1964 -Regional effects: U.S. Geological Survey Professional Paper 543-C, p. C1-C12.

Case, J.E., Burns, L.E., and Winkler, G.R., 1986, Map showing aeromagnetic survey and geologic interpretation of the Valdez quadrangle, Alaska: U.S. Geological Survey Miscellaneous Field Studies Map MF-1714, 2 sheets, scale 1:250,000.

Case, J.E., Fisher, M.A., Moore, G.W., Moore, J.C., and Nelson, S.W., 1986, Preliminary geologic interpretation of the aeromagnetic map of Afognak and Shuyak Islands, Alaska: U.S. Geological Survey Miscellaneous Field Studies Map MF-1718, 2 sheets, scale 1:250,000.

Case, J.E., and MacKevett, E.M., Jr., 1976, Aeromagnetic maps and geologic interpretation of aeromagnetic map, McCarthy quadrangle, Alaska: U.S. Geological Survey Miscellaneous Field Studies Map MF-773-D, 2 sheets, scale 1:250,000.

Case, J.E., Tysdal, R.G., Hillhouse, J.W., and Gromm, C.S., 1979, Geologic interpretation of aeromagnetic map of the Seward and Blying Sound quadrangles, Alaska: U.S. Geological Survey Miscellaneous Field Studies Map MF-880-D, 2 sheets, scale 1:250,000.

Clark, S.H.B., 1972a, The Wolverine complex, a newly discovered layered ultramafic body in the western Chugach Mountains, Alaska: U.S. Geological Survey Open-File Report 72-522, 10 p., 1 sheet, scale 1:63,360.

1972b, Reconnaissance bedrock geologic map of the Chugach Mountains near Anchorage, Alaska: U.S. Geological Survey Miscellaneous Field Studies Map MF-350, 1 sheet, scale 1:250,000.

Cobb, E.H., 1979, Summary of references to mineral occurrences (other than mineral fuels and construction materials) in the Valdez quadrangle, Alaska: U.S. Geological Survey OpenFile Report 79-1241, $166 \mathrm{p}$.

Cobb, E.H., and Matson, N.A., Jr., 1972, Metallic mineral resources map of the Valdez quadrangle, Alaska: U.S. Geological Survey Miscellaneous Field Studies Map MF-438, 1 sheet, scale $1: 250,000$.

Coleman, R.G., and Burns, L.E., 1985, The Tonsina high-pressure mafic-ultramafic cumulate sequence, Chugach Mountains, Alaska: Geological Society of America Abstracts with Programs, v. 17, no. 6, p. 348.

Coulter, H.W., and Coulter, E.B., 1961, Valdez (A-5) quadrangle, Alaska, geology: U.S. Geological Survey Geologic Quadrangle Map GQ-142, 1 sheet, scale 1:63,360.

1962, Preliminary geologic map of the Valdez-Tiekel belt, Alaska: U.S. Geological Survey Miscellaneous Geologic Investigations Map I-356, 1 sheet, scale 1:96,000.

Coulter, H.W., and Migliaccio, R.R., 1966, Effects of the earthquake of March 27, 1964, at Valdez, Alaska: U.S. Geological Survey Professional Paper 542-C, p. C1-C36.

Crowe, D.E., Nelson, S.W., Shanks, W.C., III, Brown, P.E., and Valley, J.W., in press, Geochemistry of volcanogenic massive sulfide deposits, Prince William Sound district, southcentral Alaska: Economic Geology, v. 86.

Csejtey, Béla, Jr., Cox, D.P., Evarts, R.C., Stricker, G.D., and Föster, H.L., 1982, The Cenozoic Denali fault system and the Cretaceous accretionary development of southern Alaska: Journal of Geophysical Research, v. 87, no. B5, p. 3741-3754.

Csejtey, Béla, Jr., and Griscom, Andrew, 1978, Preliminary aeromagnetic interpretive map of the Talkeetna Mountains quadrangle, Alaska: U.S. Geological Survey Open-File Report 78-558-C, 14 p., 2 sheets, scale 1:250,000.

Csejtey, Béla, Jr., Nelson, W.H., Jones, D.L., Silberling, N.J., Dean, R.M., Morris, M.S., Lanphere, M.A., Smith, J.G., and Silberman, M.L., 1978, Reconnaissance geologic map and geochronology, Talkeetna Mountains quadrangle, northern part of Anchorage quadrangle, and southwest corner of Healy quadrangle, Alaska: U.S. Geological Survey OpenFile Report 78-558-A, 62 p., 1 sheet, scale 1:250,000. 
Csejtey, Bela, Jr., and St. Aubin, D.R., 1981, Evidence for northwestward thrusting of the Talkeetna superterrane, and its regional significance, in Albert, N.R.D., and Hudson, Travis, eds., The United States Geological Survey in Alaska-Accomplishments during 1979: U.S. Geological Survey Circular 823-B, p. B49-B51.

D'Andrea, R.F., Jr., Garcia, S.R., and others, 1981, Uranium hydrogeochemical and stream sediment reconnaissance of the Valdez NTMS quadrangle, Alaska: Grand Junction, Colo., Bendix Field Engineering Corporation Report GJBX-90 (81), 65 p. Available from Books and Open-File Services Section, U.S. Geological Survey, Federal Center, Box 25046, Denver, Colorado 80225.

DeBari, S.M., and Coleman, R.G., 1989, Examination of the deep levels of an island arc-Evidence from the Tonsina ultramafic-mafic assemblage, Tonsina, Alaska: Journal of Geophysical Research, v. 94, no. B4, p. 4373-4391.

Dumoulin, J.A., 1987, Sandstone composition of the Valdez and Orca Groups, Prince William Sound, Alaska: U.S. Geological Survey Bulletin 1774, 37 p.

Engebretson, D.C., Cox, Allen, and Gordon, R.G., 1986, Relative motions between oceanic and continental plates in the Pacific Basin: Geological Society of America Special Paper 206, 59 p.

Ferrians, O.J., Jr., 1966, Effects of the earthquake of March 27, 1964, in the Copper River basin area, Alaska: U.S. Geological Survey Professional Paper 543-E, p. E1-E28.

1971, Preliminary engineering geologic maps of the proposed trans-Alaska pipeline route, Valdez quadrangle: U.S. Geological Survey Open-File Report 71-495, 2 sheets, scale $1: 125,000$.

Ferrians, O.J., Jr., Kachadoorian, Rueben, and Greene, G.W., 1969, Permafrost and related engineering problems in Alaska: U.S. Geological Survey Professional Paper 678, 37 p.

Ferrians, O.J., Jr., and Nichols, D.R., 1965, Copper River basin, in Schultz, C.B., and Smith, H.T.U., eds., Guidebook for field conference F, central and south-central Alaska: International Association for Quaternary Research Congress, 7th, Lincoln, Nebraska; Academy of Sciences, p. 93-114.

Ferrians, O.J., Jr., and Schmoll, H.R., 1957, Extensive proglacial lake of Wisconsin age in the Copper River Basin, Alaska [abs.]: Geological Society of America Bulletin, v. 68, no. 12, p. 1726.

Fisher, M.A., 1981, Location of the Border Ranges fault southwest of Kodiak Island, Alaska: Geological Society of America Bulletin, v. 92, no. 1,p. 19-30.

Fisher, M.A., Brocher, T.M., Nokleberg, W.J., Plafker, George, and Smith, G.L., 1989, Seismic reflection images of the crust of the northern part of the Chugach terrane, Alaska-Results of a survey for the Trans-Alaska Crustal Transect: Journal of Geophysical Research, v. 94, no. B4, p. 4424-4440.

Foley, J.Y., and Barker, J.C., 1985, Chromite deposits along the Border Ranges fault, southern Alaska-Part 1, Field investigations and descriptions of chromite deposits: U.S. Bureau of Mines Information Circular 8990, 58 p.

Foley, J.Y., Burns, L.E., Schneider, C.L., and Forbes, R.B., 1989, Preliminary report of platinum-group element occurrences in Alaska: Alaska Division of Geological and Geophysical Surveys Public Data File 89-20, 32 p.

Foley, J.Y., Mardock, C.L., and Dahlin, D.C., 1987, Platinumgroup elements in the Tonsina ultramafic complex, southern Alaska, in Vassiliou, A.H., Hausen, D.M., and Carson, D.J.T., eds., Process mineralogy VII-Applications to mineral beneficiation technology and mineral exploration, with special emphasis on disseminated carbonaceous gold ores: The Metallurgical Society, p. 165-195.

Fuchs, W.A., 1980, Tertiary tectonic history of the Castle Mountain-Caribou fault system in the Talkeetna Mountains: Salt Lake City, University of Utah, Ph.D. dissertation, 152 p.

Fuis, G.S., Ambos, E.L., Mooney, W.D., Christensen, N.I., and Geist, Eric, 1991, Crustal structure of accreted terranes in southern Alaska, Chugach Mountains, and Copper River basin from seismic refraction results: Journal of Geophysical Research, v. 96, no. B3, p. 4187-4227.

Fuis, G.S., and Plafker, George, 1991, Evolution of deep structure along the Trans-Alaska Crustal Transect, Chugach Mountains and Copper River Basin, southern Alaska: Journal of Geophysical Research, v. 96, no. B3, p. 4229-4253.

Gardner, M.C., MacKevett, E.M., Jr., and McClelland, W.D., 1986, The Chitina fault system of southern Alaska-An early Cretaceous collisional suture zone: Geological Society of America Abstracts with Programs, v. 18, no. 2, p. 108.

Gilbert, G.K., 1904, Glaciers and glaciation: Harriman Alaska Expedition, v. 3, 176 p.

Goldfarb, R.J., 1989, Genesis of lode gold deposits of the southern Alaska Cordillera: Golden, Colorado School of Mines, Ph.D. dissertation, 437 p.

Goldfarb, R.J., Borden, J.C., and Winkler, G.R., in press, Geochemical survey of the Valdez $1^{\circ} \times 3^{\circ}$ quadrangle, southcentral Alaska: U.S. Geological Survey Bulletin, 2 sheets, scale 1:250,000.

Goldfarb, R.J., Leach, D.L., Miller, M.L., and Pickthorn, W.J., 1986, Geology, metamorphic setting, and genetic constraints of epigenetic lode-gold mineralization within the Cretaceous Valdez Group, south-central Alaska, in Keppie, J.D., Boyle, R.W., and Haynes, S.J., eds., Turbidite-hosted gold deposits: Geological Association of Canada Special Paper 32, p. 87-105.

Goldfarb, R.J., Nelson, S.W., Dumoulin, J.A., and Miller, M.L., 1984, Data report and statistical summary for samples of moraine and stream sediment, nonmagnetic heavy-mineral concentrate, and rock samples from the Chugach National Forest, Alaska: U.S. Geological Survey Open-File Report 84-355, $466 \mathrm{p}$.

Grant, U.S., 1906, Copper and other mineral resources of Prince William Sound: U.S. Geological Survey Bulletin 284, p. 78-87.

1909, Gold on Prince William Sound: U.S. Geological Survey Bulletin 379-C, p. 97.

Grant, U.S., and Higgins, D.F., Jr., 1909, Copper mining and prospecting on Prince William Sound: U.S. Geological Survey Bulletin 379-C, p. 87-96.

1910 , Reconnaissance of the geology and mineral resources of Prince William Sound, Alaska: U.S. Geological Survey Bulletin 443, 89 p.

Grantz, Arthur, 1964, Stratigraphic reconnaissance of the Matanuska Formation in the Matanuska Valley, Alaska: U.S. Geological Survey Bulletin 1181-I, p. I1-I33.

1965, Geologic map and cross-sections of the Nelchina area, south-central Alaska: U.S. Geological Survey OpenFile Report 65-65, 4 sheets, scale 1:48,000.

Grantz, Arthur, Jones, D.L., and Lanphere, M.A., 1966, Stratigraphy, paleontology, and isotopic ages of Upper Mesozoic rocks in the southwestern Wrangell Mountains, Alaska, in Geological Survey Research 1966: U.S. Geological Survey Professional Paper 550-C, p. Q39-C47.

Grantz, Arthur, Zietz, Isidore, and Andreason, G.E., 1963, An aeromagnetic reconnaissance of the Cook Inlet area, Alaska: 
U.S. Geological Survey Professional Paper 316-G, p. 117-134.

Griscom, Andrew, 1975, Aeromagnetic map and interpretation of the Nabesna quadrangle, Alaska: U.S. Geological Survey Miscellaneous Field Studies Map MF-665-H, 2 sheets, scale $1: 250,000$.

Hayes, C.W., 1892, An expedition through the Yukon district: National Geographic Magazine, v. 4, p. 117-162.

Herreid, Gordon, 1970, Geology of the Spirit Mountain nickel-copper prospect and surrounding area: Alaska Division of Mines and Geology Geologic Report 40, 19 p.

Hoffman, B.L., 1974, Geology of the Bernard Mountain area, Tonsina, Alaska: Fairbanks, University of Alaska, M.S. thesis, $68 \mathrm{p}$.

Hollister, L.S., 1979, Metamorphism and crustal displacements-New insights: Episodes, v. 1979, no. 3, p. 3-8.

Hudson, Travis, 1979, Mesozoic plutonic belts of southern Alaska: Geology, v. 7, p. 230-234.

1983, Calc-alkaline plutonism along the Pacific rim of southern Alaska, in Roddick, J.A., ed., Circum-Pacific plutonic terranes: Geological Society of America Memoir 159, p. 159-170.

Hudson, Travis, and Plafker, George, 1982, Paleogene metamorphism of an accretionary flysch terrane, eastern Gulf of Alaska: Geological Society of America Bulletin, v. 93, p. 1280-1290.

Hudson, Travis, Plafker, George, and Peterman, Z.E., 1979, Paleogene anatexis along the Gulf of Alaska margin: Geology, v. 7 , no. 12, p. 573-577.

Imlay, R.W., and Detterman, R.L., 1973, Jurassic paleobiogeography of Alaska: U.S. Geological Survey Professional Paper 801,34 p.

Jansons, Uldis, Hoekzema, R.B., Kurtak, J.M., and Fechner, S.A., 1984, Mineral occurrences in the Chugach National Forest, southcentral Alaska: U.S. Bureau of Mines Mineral Lands Assessment Report MLA 5-84, 218 p., 2 sheets, scale $1: 250,000$.

Jasper, M.W., 1967, Geochemical investigations along the Valdez to Chitina Highway in southcentral Alaska, 1966: Alaska Division of Mines and Geology Geochemical Report 15, 19 p.

Johnson, B.L., 1915, The gold and copper deposits of the Port Valdez district, Alaska: U.S. Geological Survey Bulletin 622-E, p. 140-188.

1916, Mining on Prince William Sound: U.S. Geological Survey Bulletin 642, p. 137-145.

1919, Mineral resources of Jack Bay district and vicinity, Prince William Sound, Alaska: U.S. Geological Survey Bulletin 692-C, p. 153-174.

Jones, D.L., Silberling, N.J., Coney, P.J., and Plafker, George, 1987, Lithotectonic terrane map of Alaska (west of the 41st meridian): U.S. Geological Survey Miscellaneous Field Studies Map MF-1874-A, 1 sheet, scale 1:2,500,000.

Jones, D.L., Silberling, N.J., and Hillhouse, J.W., 1977, Wrangellia-A displaced terrane in northwestern North America: Canadian Journal of Earth Sciences, v. 14, p. 2565-2577.

Kingston, Jack, and Miller, D.J., 1945, Nickel-copper prospect near Spirit Mountain, Copper River region, Alaska: U.S. Geological Survey Bulletin 943-C, p. 49-57.

Le Compte, J.R., 1981, Map showing interpretation of Landsat imagery of the Valdez $1^{\circ} \times 3^{\circ}$ quadrangle, southern Alaska: U.S. Geological Survey Open-File Report 80-892-F, 1 sheet, scale 1:250,000.

Little, T.A., 1990, Kinematics of wrench and divergent-wrench deformation along a central part of the Border Ranges fault system, northern Chugach Mountains, Alaska: Tectonics, $v$. 9 , no. 4, p. 585-611.

Little, T.A., and Naeser, C.W., 1989, Tertiary tectonics of the Border Ranges fault system, Chugach Mountains, Alaska-Deformation and uplift in a forearc setting: Journal of Geophysical Research, v. 94, no. B4, p. 4333-4359.

Los Alamos National Laboratory, 1983, The geochemical atlas of Alaska: Grand Junction, Colo., Bendix Field Engineering Corporation Report GJBX-32(83), 57 p. Available from Books and Open-File Services Section, U.S. Geological Survey, Federal Center, Box 25046, Denver, Colorado 80225.

Lull, J.S., and Plafker, George, 1990, Geochemistry and paleotectonic implications of metabasaltic rocks in the Valdez Group, southern Alaska, in Dover, J.H., and Galloway, J.P., eds., Geologic studies in Alaska by the U.S. Geological Survey, 1989: U.S. Geological Survey Bulletin 1946, p. 29-38.

MacKevett, E.M., Jr., 1976, Mineral deposits and occurrences in the McCarthy quadrangle, Alaska: U.S. Geological Survey Miscellaneous Field Studies Map MF-773-B, 1 sheet, scale $1: 250,000$.

1978, Geologic map of the McCarthy quadrangle, Alaska: U.S. Geological Survey Miscellaneous Investigations Series Map I-1032, 1 sheet, scale 1:250,000.

MacKevett, E.M., Jr., Albert, N.R.D., Barnes, D.F., Case, J.E., Robinson, Keith, and Singer, D.A., 1977, The Alaskan Mineral Resource Assessment Program-Background information to accompany folio of geologic and mineral resource maps of the McCarthy quadrangle, Alaska: U.S. Geological Survey Circular 739, 23 p.

MacKevett, E.M., Jr., and Plafker, George, 1974, The Border Ranges fault in south-central Alaska: U.S. Geological Survey Journal of Research, v. 2, no. 3, p. 323-329.

MacKevett, E.M. Jr., Smith, J.G., Jones, D.L., and Winkler, G.R., 1978, Geologic map of the McCarthy C-8 quadrangle, Alaska: U.S. Geological Survey Geologic Quadrangle Map GQ-1418, 1 sheet, scale 1:63,360.

Madden-McGuire, D.J., and Winkler, G.R., in press, Mineralresource maps of the Anchorage $1^{\circ} \times 3^{\circ}$ quadrangle, southem Alaska: U.S. Geological Survey Miscellaneous Field Studies Map, scale 1:250,000.

Mendenhall, W.C., 1905, Geology of the central Copper River region, Alaska: U.S. Geological Survey Professional Paper $41,133 \mathrm{p}$.

Mendenhall, W.C., and Schrader, F.C., 1903, The mineral resources of the Mount Wrangell district, Alaska: U.S. Geological Survey Professional Paper 15, 71 p.

Metz, P.A., 1976, Occurrences of sodic-amphibole-bearing rocks in the Valdez C-2 quadrangle, in Short notes on Alaskan geology, 1975: Alaska Division of Geological and Geophysical Surveys Geologic Report 51, p. 27-28.

Miller, D.J., Payne, T.G., and Gryc, George, 1959, Geology of possible petroleum provinces in Alaska, with an annotated bibliography, by E.H. Cobb: U.S. Geological Survey Bulletin 1094, $131 \mathrm{p}$.

Miller, R.J., Winkler, G.R., O'Leary, R.M., and Cooley, E.F., 1982 Analyses of rock, stream-sediment, and heavy-mineral concentrate samples from the Valdez quadrangle, Alaska: U.S. Geological Survey Open-File Report 82-451, 224 p., 2 sheets, scale 1:250,000.

Moffit, F.H., 1908, Notes on copper prospects of Prince William Sound: U.S. Geological Survey Bulletin 345-C, p. 176-178. 1912, The Taral and Bremner River districts: U.S. Geological Survey Bulletin 520, p. 93-104.

1914, Geology of the Hanagita-Bremner region, Alaska: U.S. Geological Survey Bulletin 576, 56 p. 
1918, Mining in the lower Copper River Basin: U.S. Geological Survey Bulletin 662, p. 177-182.

1935, Geology of the Tonsina district, Alaska: U.S. Geological Survey Bulletin 866, 38 p.

1954, Geology of the Prince William Sound region, Alaska: U.S. Geological Survey Bulletin 989-E, p. 225-310.

Moffit, F.H., and Capps, S.R., 1911, Geology and mineral resources of the Nizina district, Alaska: U.S. Geological Survey Bulletin 448, $111 \mathrm{p}$.

Moffit, F.H., and Fellows, R.E., 1951, Copper deposits of the Prince William Sound district, Alaska: U.S. Geological Survey Bulletin 963-B, p. 47-80.

Moffit, F.H., and Maddren, A.G., 1909, Mineral resources of the Kotsina-Chitina region, Alaska: U.S. Geological Survey Bulletin 374, 103 p.

Moffit, F.H., and Mertie, J.B., Jr., 1923, The Kotsina-Kuskulana district, Alaska: U.S. Geological Survey Bulletin 745, 149 p.

Monger, J.W.H., Price, R.A., and Templeman-Kluit, D.J., 1982, Tectonic accretion and the origin of the two major metamorphic and plutonic welts in the Canadian Cordillera: Geology, v. 10, no. 2, p. 70-75.

Nelson, S.W., Dumoulin, J.A., and Miller, M.L., 1985, Geologic map of the Chugach National Forest, Alaska: U.S. Geological Survey Miscellaneous Field Studies Map MF-1645-B, 16 p., 1 sheet, scale 1:250,000.

Nelson, S.W., and Koski, R.A., 1987, The Midas mine-A stratiform $\mathrm{Fe}-\mathrm{Cu}-\mathrm{Zn}-\mathrm{Pb}$ sulfide deposit in late Cretaceous turbidite near Valdez, Alaska: Geological Society of America Abstracts with Programs, v. 19, no. 6, p. 436.

Nelson, S.W., Miller, M.L., Barnes, D.F., Dumoulin, J.A., Goldfarb, R.J., Koski, R.A., Mull, C.G., Pickthom, W.J., Jansons, Uldis, Hoekzema, R.B., Kurtak, J.M., and Fechner, S.A., 1984, Mineral resource potential map of the Chugach National Forest, Alaska: U.S. Geological Survey Miscellaneous Field Studies Map MF-1645-A, 24 p., 1 sheet, scale $1: 250,000$.

Newberry, R.J., 1986, Mineral resources of the northcentral Chugach Mountains, Alaska: Alaska Division of Geological and Geophysical Surveys Report of Investigations 86-23, 44 p.

Nichols, D.R., 1965, Glacial history of the Copper River Basin Alaska [abs.]: International Association for Quaternary Research Congress, 7th, Proceedings, v. 22, p. 360.

Nichols, D.R., and Yehle, L.A., 1969, Engineering geologic map of the southeastem Copper River Basin, Alaska: U.S. Geological Survey Miscellaneous Geologic Investigations Map I-524, 1 sheet, scale 1:125,000.

Nilsen, T.H., and Zuffa, G.G., 1982, The Chugach terrane, a Cretaceous trench-fill deposit, southern Alaska, in Trench-forearc geology-Sedimentation and tectonics on modern and ancient active plate margins: Geological Society of London Special Publication 10, p. 213-227.

Nokleberg, W.J., Plafker, George, Lull, J.S., Wallace, W.K., and Winkler, G.R., 1989, Structural analysis of the southern Peninsular, southern Wrangellia, and northern Chugach terranes along the Trans-Alaska Crustal Transect, northern Chugach Mountains, Alaska: Journal of Geophysical Research, v. 94, no. B4, p. 4297-4320.

Nokleberg, W.J., Wade, W.M., Lange, I.M., and Plafker, George, 1986, Summary of geology of the Peninsular terrane, metamorphic complex of Gulkana River, and Wrangellia terranes, north-central and northwestem Gulkana quadrangle, in Bartsch-Winkler, Susan, and Reed, K.M., eds., Geologic studies in Alaska by the U.S. Geological Survey during 1985: U.S. Geological Survey Circular 978, p. 69-74.
Overbeck, R.M., 1918, Nickel deposits in the lower Copper River Valley: U.S. Geological Survey Bulletin 712, p. 91-98.

Page, R.A., Boore, D.M., Joyner, W.B., and Coulter, H.W., 1972, Ground motion values for use in the seismic design of the Trans-Alaska Pipeline System: U.S. Geological Survey Circular 672, 23 p.

Page, R.A., Plafker, George, Fuis, G.S., Nokleberg, W.J., Ambos, E.L., Mooney, W.D., and Campbell, D.L., 1986, Accretion and subduction tectonics in the Chugach Mountains and Copper River Basin, Alaska-Initial results of the TransAlaska Crustal Transect: Geology, v. 14, p. 501-505.

Page, R.A., Stephens, C.D., and Lahr, J.C., 1989, Seismicity of the Wrangell and Aleutian Wadati-Benioff zones and the North American plate along the Trans-Alaska Crustal Transect, Chugach Mountains and Copper River basin, southern Alaska: Journal of Geophysical Research, v. 94, no. B11, p. 16059-16082.

Pavlis, T.L., 1982, Origin and age of the Border Ranges fault of southern Alaska and its bearing on the late Mesozoic evolution of Alaska: Tectonics, v. 1, no. 4, p. 343-368. 1983, Pre-Cretaceous crystalline rocks of the western Chugach Mountains, Alaska-Nature of the basement of the Jurassic Peninsular terrane: Geological Society of America Bulletin, v. 94, no. 11, p. 1329-1344.

Pavlis, T.L., and Crouse, G.W., 1989. Late Mesozoic strike-slip movement on the Border Ranges fault system in the eastem Chugach Mountains, southern Alaska: Journal of Geophysical Research, v. 94, no. B4, p. 4321-4332.

Pavlis, T.L., Monteverde, D.H., Bowman, J.R., Rubenstone, J.L., and Reason, M.D., 1988, Early Cretaceous near-trench plutonism in southern Alaska-A tonalite-trondhjemite intrusive complex injected during ductile thrusting along the Border Ranges fault system: Tectonics, v. 7, no. 6, p. 1179-1199.

Pickthorn, W.J., 1982, Stable isotope and fluid inclusion study of the Port Valdez district, southern Alaska: Los Angeles, University of California, M.S. thesis, $66 \mathrm{p}$.

Pickthorn, W.J., Goldfarb, R.J., and Winkler, G.R., in press, Maps showing areas with potential for undiscovered resources of precious-, base-, and ferrous-metals in the Valdez quadrangle, south-central Alaska: U.S. Geological Survey Miscellaneous Field Studies Map, 2 sheets, scale 1:250,000.

Pickthorn, W.J., and Silberman, M.L. 1984, Structural relations and fluid-inclusion data for mineralized and nonmineralized veins in the Port Valdez gold district, Valdez quadrangle, southern Alaska, in Coonrad, W.L., and Elliott, R.L., eds., The United States Geological Survey in Alaska-Accomplishments during 1981: U.S. Geological Survey Circular 868, p. 86-89.

Plafker, George, 1969, Tectonics of the March 27, 1964, Alaska earthquake, in The Alaska earthquake, March 27, 1964-Regional effects: U.S. Geological Survey Professional Paper 543-I, p. I1-I74.

1987, Regional geology and petroleum potential of the northern Gulf of Alaska continental margin, in Scholl, D.W., Grantz, Arthur, and Vedder, J.G. eds., Geology and resource potential of the continental margin of western North America and adjacent ocean basins: [Houston] Circum-Pacific Council for Energy and Mineral Resources, Earth Science Series 6, p. 229-268.

Plafker, George, Harris, A.G., and Reed, K.M., 1985, Early Pennsylvanian conodonts from the Strelna Formation, Chitina Valley area, in Bartsch-Winkler, Susan, ed., The United States Geological Survey in Alaska-Accomplishments during 1984: U.S. Geological Survey Circular 967, p. 76-79. 
Plafker, George, Jones, D.L., and Pessagno, E.A., Jr., 1977, A Cretaceous accretionary flysch and melange terrane along the Gulf of Alaska margin, in Blean, K.M., ed., The United States Geological Survey in Alaska-Accomplishments during 1976: U.S. Geological Survey Circular 751-B, p. B41-B43.

Plafker, George, and Lanphere, M.A., 1974, Age of the Bagley fault, in Carter, Claire, ed., United States Geological Survey Alaska program, 1974: U.S. Geological Survey Circular 700, p. 52.

Plafker, George, Lull, J.S., Nokleberg, W.J., Pessel, G.H., Wallace, W.K., and Winkler, G.R., 1989, Geologic map of the Valdez A-4, B-3, B-4, C-3, C-4, and D-4 quadrangles, northern Chugach Mountains and southern Copper River basin, Alaska: U.S. Geological Survey Open-File Report 89-569, 1 sheet, scale 1:125,000.

Plafker, George, Nokleberg, W.J., and Lull, J.S., 1985, Summary of 1984 TACT geologic studies in the northern Chugach Mountains and southern Copper River basin, in Bartsch-Winkler, Susan, ed., The United States Geological Survey in Alaska-Accomplishments during 1984: U.S. Geological Survey Circular 967, p. 76-79.

1989, Bedrock geology and tectonic evolution of the Wrangellia, Peninsular, and Chugach terranes along the Trans-Alaska Crustal Transect in the northern Chugach Mountains and southern Copper River basin, Alaska: Journal of Geophysical Research, v. 94, no. B4, p. 4255-4295.

Plafker, George, Nokleberg, W.J., Lull, J.S., Roeske, S.M., and Winkler, G.R., 1986, Nature and timing of deformation along the Contact fault system in the Cordova, Bering Glacier, and Valdez quadrangles, in Bartsch-Winkler, Susan, and Reed, K.M., eds., Geologic studies in Alaska by the U.S. Geological Survey during 1985: U.S. Geological Survey Circular 978, p. 74-77.

Post, Austin, and Mayo, L.R., 1971, Glacier dammed lakes and outburst floods in Alaska: U.S. Geological Survey Hydrologic Investigations Atlas HA-455, 3 sheets, scale 1:1,000,000.

Richter, D.H., and Jones, D.L., 1973, Structure and stratigraphy of eastern Alaska Range, Alaska: American Association of Petroleum Geologists Memoir 19, p. 408-420.

Roeske, S.M., 1986, Field relations and metamorphism of the Raspberry Schist, Kodiak Islands, Alaska, in Evans, B.W., and Brown, E.H., eds., Blueschists and eclogites: Geological Society of America Memoir 164, p. 169-184.

Rohn, Oscar, 1900, A reconnaissance of the Chitina River and the Skolai Mountains, Alaska: U.S. Geological Survey Annual Report 21, pt. 2, p. 393-440.

Rose, A.W., 1965, Geology and mineralization of the Midas mine and Sulphide Gulch areas near Valdez, Alaska: Alaska Division of Mines and Minerals Geologic Report 15, 21 p.

Schrader, F.C., 1900, A reconnaissance of a part of Prince William Sound and the Copper River district, Alaska, in 1898, by Frank Charles Schrader: U.S. Geological Survey Annual Report 20, pt. 7, 368 p.

Schrader, F.C., and Spencer, A.C., 1901, The geology and mineral resources of a portion of the Copper River district, Alaska: U.S. Geological Survey Special Publication, 94 p.

Sharp, R.R., Jr., and Hill, D.E., 1978, Uranium concentrations in stream waters and sediments from selected sites in the eastem Seward Peninsula, Koyukuk, and Charley River areas, and across south-central Alaska: Los Alamos Scientific Laboratory Informal Report LA-6649-MS, 125 p. Available from Books and Open-Files Services Section, U.S. Geological Survey, Federal Center, Box 25046, Denver, Colorado 80225.
Singer, D.A., and MacKevett, E.M., Jr., 1976, Mineral resources map of the McCarthy quadrangle, Alaska: U.S. Geological Survey Miscellaneous Field Studies Map MF-773-C, 1 sheet, scale 1:250,000.

Sisson, V.B., Hollister, L.S., and Onstott, T.C., 1989, Petrologic and age constraints on the origin of a low-pressure/high-temperature metamorphic complex, southern Alaska: Journal of Geophysical Research, v. 94, no. B4, p. 4392-4410.

Sisson, V.B., and Onstott, 1986, Dating blueschist metamorphism-A combined ${ }^{49} \mathrm{Ar} /{ }^{39} \mathrm{Ar}$ and electron microprobe approach: Geochimica et Cosmochimica Acta, v. 50, p. 2111-2117.

Smith, J.G., and MacKevett, E.M., Jr., 1970, The Skolai Group in the McCarthy B-4, C-4, and C-5 quadrangles, Wrangell Mountains, Alaska: U.S. Geological Survey Bulletin 1274-Q, p. Q1-Q26.

Smith, R.L., and Shaw, H.R., 1975, Igneous-related geothermal systems, in White, D.E., and Williams, D.L., eds., Assessment of geothermal resources of the United States-1975: U.S. Geological Survey Circular 726, p. 58-83.

Sutley, S.J., Goldfarb, R.J., O'Leary, R.M., and Tripp, R.B., 1990, A comparison of geochemical exploration techniques and sample media within accretionary continental margins-An example from the Pacific Border Ranges, southern Alaska, U.S.A.: Journal of Geochemical Exploration, v. 37, p. 255-275.

Tysdal, R.G., and Case, J.E., 1979, Geologic map of the Seward and Blying Sound quadrangles, Alaska: U.S. Geological Survey Miscellaneous Investigations Series Map I-1150, 12 p. 1 sheet, scale 1:250,000.

1982, Metalliferous mineral resource potential of the Seward and Blying Sound quadrangles, southern Alaska: U.S. Geological Survey Miscellaneous Field Studies Map MF-880-H, 1 sheet, scale 1:250,000.

U.S. Geological Survey, 1979, Aeromagnetic map of part of the Valdez quadrangle, Alaska: U.S. Geological Survey OpenFile Report 79-381, 1 sheet, scale 1:250,000.

Williams, J.R., 1970, Ground water in the permafrost regions of Alaska: U.S. Geological Survey Professional Paper 696, 83 p.

Williams, J.R., and Coulter, H.W., 1980, Deglaciation and sea-level fluctuations in Port Valdez, Alaska, in Albert, N.R.D., and Hudson, Travis, eds., The United States Geological Survey in Alaska-Accomplishments during 1979: U.S. Geological Survey Circular 823-B, p. B78-B80.

Williams, J.R., and Johnson, K.M., 1981, Map and description of the late Tertiary and Quaternary deposits, Valdez quadrangle, Alaska: U.S. Geological Survey Open-File Report 80-892-C, 2 sheets, scale 1:250,000.

Winkler, G.R., 1976, Deep-sea fan deposition of the lower Tertiary Orca Group, eastern Prince William Sound, Alaska, in Miller, T.P., ed., Recent and ancient sedimentary environments in Alaska: [Anchorage] Alaska Geological Society, p. R1-R20. 1990, Preliminary geologic map, cross sections, and summary geochronology of the Anchorage quadrangle, southern Alaska: U.S. Geological Survey Open-File Report 90-83, 2 sheets, scale 1:250,000.

1992, Geologic map and summary geochronology of the Anchorage $1^{\circ} \times 3^{\circ}$ quadrangle, southern Alaska: U.S. Geological Survey Miscellaneous Geologic Investigations Map I-2283, 1 sheet, scale 1:250,000.

Winkler, G.R., Miller, R.J., and Case, J.E., 1981, Blocks and belts of blueschist and greenschist in the northwestern Valdez quadrangle, in Albert, N.R.D., and Hudson, Travis, The 
United States Geological Survey in Alaska-Accomplishments during 1979: U.S. Geological Survey Circular 823-B, p. B72-B74.

Winkler, G.R., Miller, R.J., MacKevett, E.M., Jr., and Holloway, C.D., 1981, Map and summary table describing mineral deposits in the Valdez quadrangle, southern Alaska: U.S. Geological Survey Open-File Report 80-892-B, 1 sheet, scale 1:250,000.

Winkler, G.R., Miller, R.J., Silberman, M.L., Grantz, Arthur, Case, J.E., and Pickthorn, W.J., 1981, Layered gabbroic belt of regional extent in the Valdez quadrangle, in Albert, N.R.D., and Hudson, Travis, The United States Geological Survey in Alaska-Accomplishments during 1979: U.S. Geological Survey Circular 823-B, p. B74-B76.

Winkler, G.R., and Plafker, George, 1975, The Landlock faultPart of a major early Tertiary plate boundary in southern Alaska, in Yount, M.E., ed., United States Geological Survey Alaska program, 1975: U.S. Geological Survey Circular 722, p. 49.

1981, Geologic map and cross sections of the Cordova and Middleton Island quadrangles, southern Alaska: U.S. Geological Survey Open-File Report 81-1164, 25 p., 1 sheet, scale 1:250,000.
1992, Geologic map of the Cordova and Middleton Island quadrangles, southern Alaska: U.S. Geological Survey Miscellaneous Geologic Investigations Series Map I-1984, 1 sheet, scale 1:250,000.

Winkler, G.R., Silberman, M.L., Grantz, Arthur, Miller, R.J., and MacKevett, E.M., Jr., 1981, Geologic map and summary geochronology of the Valdez quadrangle, southern Alaska: U.S. Geological Survey Open-File Report 80-892-A, 2 sheets, scale $1: 250,000$.

Winkler, G.R., and Tysdal, R.G., 1977, Conglomerates in flysch of the Orca Group, Prince William Sound, in Blean, K.M., ed., The United States Geological Survey in Alaska-Accomplishments during 1976: U.S. Geological Survey Circular 751-B, p. B43-B44.

Yehle, L.A., and Nichols, D.R., 1980, Reconnaissance map and description of the Chetaslina volcanic debris flow (new name), southeastern Copper River basin and adjacent areas, south-central Alaska: U.S. Geological Survey Miscellaneous Field Studies Map MF-1209, 1 sheet, scale 1:250,000.

Zuffa, G.G., Nilsen, T.H., and Winkler, G.R., 1980, Rock-fragment petrography of Upper Cretaceous Chugach terrane, southern Alaska: U.S. Geological Survey Open-File Report 80-713, $28 \mathrm{p}$. 




\section{SELECTED SERIES OF U.S. GEOLOGICAL SURVEY PUBLICATIONS}

\section{Periodicals}

Earthquakes \& Volcanoes (issued bimonthly).

Preliminary Determination of Epicenters (issued monthly).

\section{Technical Books and Reports}

Professional Papers are mainly comprehensive scientific reports of wide and lasting interest and importance to professional scientists and engineers. Included are reports on the results of resource studies and of topographic, hydrologic, and geologic investigations. They also include collections of related papers addressing different aspects of a single scientific topic.

Bulletins contain significant data and interpretations that are of lasting scientific interest but are generally more limited in scope or geographic coverage than Professional Papers. They include the results of resource studies and of geologic and topographic investigations; as well as collections of short papers related to a specific topic.

Water-Supply Papers are comprehensive reports that present significant interpretive results of hydrologic investigations of wide interest to professional geologists, hydrologists, and engineers. The series covers investigations in all phases of hydrology, including hydrology, availability of water, quality of water, and use of water.

Circulars present administrative information or important scientific information of wide popular interest in a format designed for distribution at no cost to the public. Information is usually of short-term interest.

Water-Resources Investigations Reports are papers of an interpretive nature made available to the public outside the formal USGS publications series. Copies are reproduced on request unlike formal USGS publications, and they are also available for public inspection at depositories indicated in USGS catalogs.

Open-File Reports include unpublished manuscript reports, maps, and other material that are made available for public consultation at depositories. They are a nonpermanent form of publication that maybe cited in other publications as sources of information.

\section{Maps}

Geologic Quadrangle Maps are multicolor geologic maps on topographic bases in $71 / 2$ - or 15-minute quadrangle formats (scales mainly $1: 24,000$ or $1: 62,500$ ) showing bedrock, surficial, or engineering geology. Maps generally include brief texts; some maps include structure and columnar sections only.

Geophysical Investigations Maps are on topographic or planimetric bases at various scales, they show results of surveys using geophysical techniques, such as gravity, magnetic, seismic, or radioactivity, which reflect subsurface structures that are of economic or geologic significance. Many maps include correlations with the geology.

Miscellaneous Investigations Series Maps are on planimetric or topographic bases of regular and irregular areas at various scales; they nt a wide variety of format and subject matter. The series also inclutes 7 1/2-minute quadrangle photogeologic maps on planimetric bases which show geology as interpreted from aerial photographs. The series also includes maps of Mars and the Moon.
Coal Investigations Maps are geologic maps on topographic or planimetric bases at various scales showing bedrock or surficial geology, stratigraphy, and structural relations in certain coal-resource areas.

Oil and Gas Investigations Charts show stratigraphic information for certain oil and gas fields and other areas having petroleum potential.

Miscellaneous Field Studies Maps are multicolor or black-andwhite maps on topographic or planimetric bases on quadrangle or irregular areas at various scales. Pre-1971 maps show bedrock geology in relation to specific mining or mineral-deposit problems; post-1971 maps are primarily black-and-white maps on various subjects such as environmental studies or wilderness mineral investigations.

Hydrologic Investigations Atlases are multicolored or black-andwhite maps on topographic or planimetric bases presenting a wide range of geohydrologic data of both regular and irregular areas; the principal scale is $1: 24,000$, and regional studies are at 1:250,000 scale or smaller.

\section{Catalogs}

Permanent catalogs, as well as some others, giving comprehensive listings of U.S. Geological Survey publications are available under the conditions indicated below from the U.S. Geological Survey, Books and Open-File Reports Sales, Box 25425, Denver, CO 80225. (See latest Price and Availability List.)

"Publications of the Geological Survey, 1879-1961" may be purchased by mail and over the counter in paperback book form and as a set microfiche.

"Publications of the Geological Survey, 1962-1970" may be purchased by mail and over the counter in paperback book form and as a set of microfiche.

"Publications of the U.S. Geological Survey, 1971-1981" may be purchased by mail and over the counter in paperback book form (two volumes, publications listing and index) and as a set of microfiche.

Supplements for 1982, 1983, 1984, 1985, 1986, and for subsequent years since the last permanent catalog may be purchased by mail and over the counter in paperback book form.

State catalogs, "List of U.S. Geological Survey Geologic and Water-Supply Reports and Maps For (State)," may be purchased by mail and over the counter in paperback booklet form only.

"Price and Availability List of U.S. Geological Survey Publications," issued annually, is available free of charge in paperback booklet form only.

Selected copies of a monthly catalog "New Publications of the U.S. Geological Survey" is available free of charge by mail or may be obtained over the counter in paperback booklet form only. Those wishing a free subscription to the monthly catalog "New Publications of the U.S. Geological Survey" should write to the U.S. Geological Survey, 582 National Center, Reston, VA 22092.

Note.-Prices of Government publications listed in older catalogs, announcements, and publications may be incorrect. Therefore, the prices charged may differ from the prices in catalogs, announcements, and publications. 


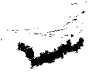

